\title{
Effect of Locust Bean Pod Ash and Eggshell Ash on the Mortar Compressive and Flexural Strengths of Cement Blends
}

\author{
Olumide Olu Olubajo ${ }^{1}$, Abubakar Jibril ${ }^{1}$, Odey Ade Osha ${ }^{2}$
}

\author{
${ }^{1}$ Abubakar Tafawa Balewa University \\ Dass road, P. M. B. 0248, Bauchi, 740272, Nigeria \\ ${ }^{2}$ University of Calabar \\ Etagbor, P. M. B. 1115, Cross River State, Nigeria
}

DOl: $10.22178 /$ pos.56-2

LCC Subject Category: QD1-65

Received 28.02.2020

Accepted 29.03.2020

Published online 31.03.2020

Corresponding Author:

Olumide Olu Olubajo

ooolubajo@atbu.edu.ng

(C) 2020 The Authors. This

article is licensed under a

Creative Commons

Attribution 4.0 License

(c) (1)
Abstract. An increase in the generation of biogenic wastes such as locust bean pods and eggshells coupled with the need to drive sustainability in the cement industry has led the use of these wastes as cement replacement materials. The paper aims to investigate the effect of locust bean pod ash (LBPA) and eggshell ash (ESA) on the mortar compressive and flexural strength of ternary cement blends. The LBPA was obtained by calcining locust bean pod (LBP) at various temperatures of $800-900{ }^{\circ} \mathrm{C}$ and time of $60-120$ minutes at an interval of $50{ }^{\circ} \mathrm{C}$ and 30 minutes respectively to determine the optimal conditions. The chemical composition of Ordinary Portland cement (OPC), LBPA and ESA were obtained via X-ray Fluorescence (XRF) Spectrometer and LBPA chemical composition did not satisfy one of the requirements specified by ASTM C618-01 (2001) with $\mathrm{SiO}_{2}+\mathrm{Al}_{2} \mathrm{O}_{3}+\mathrm{Fe}_{2} \mathrm{O}_{3}$ of $30.42 \mathrm{wt}$. \% which is less than $50 \mathrm{wt}$. \%, but satisfies $\mathrm{SO}_{3}$ content requirement of 0.7 wt. \% and Loss on Ignition (LOI) of 7.12 wt. \% and contains 19.42 wt. \% $\mathrm{CaO}$ which is within the range of $10-30$ wt. \% $\mathrm{CaO}$ is class $\mathrm{C}$ pozzolan. The compressive strength of blended cement mortars at the early age of 2 and 7 days produced better strengths for cement blends with higher ESA content than LBPA especially at LBPA/LBPA-ESA ratio of $0,0.4$ and 0.6 for 2.5 wt. \% cement replacement respectively. The early strength gain could be attributed to the provision of more nucleation sites by ESA inclusion which results in the acceleration of cement hydration rate. On the other hand, the enhanced strengths at 28 days of cement blended with various replacement from $2.5-10$ wt. \% could be attributed to the pozzolanic reaction between the available lime and reactive silica from LBPA despite clinker diminution which was close to control. Another reason for enhanced strength' could be attributed to the increased potassium content by an increase in LBPA content resulting in a gradual strength gain (retarder) muscovite formation $\mathrm{K}_{2} \mathrm{Al}_{2} \mathrm{Si}_{6} \mathrm{Al}_{4} \mathrm{O}_{20}(\mathrm{OH})_{4}$. All cement blends experienced an increase in the mortar compressive and flexural strengths as the curing day progressed with some blends producing enhanced strength compared to control especially with 1.5 ESA1LBPA produced the best strength at $50.15(6.82) \mathrm{N} / \mathrm{mm}^{2}$ against 48.80 $(6.80) \mathrm{N} / \mathrm{mm}^{2}$. This enhanced strength could be related to the pozzolanic activity and the high potassium content from LBPA despite clinker diminution, especially at 28 days.

Keywords: Locust Bean Pod Ash; Eggshell Ash; Compressive Strength; Flexural Strength Pozzolan; Flexural Strength; Cement blends.

\section{INTRODUCTION}

The demand for cement arising from inadequate housing coupled with the need to solve the problem of release of $\mathrm{CO}_{2}$ leading to the greenhouse effect and an enormous amount of energy is required for cement production. Cement is a widely employed construction material owing to its sta- bility and flexibility in designs of building structures with advantages ranging from built-in fire resistance, high compressive strength to low maintenance [31]. One alternative solution to these challenges is the partial replacement of cement by appropriate materials such as pozzolans. These pozzolanic materials are siliceous or aluminous materials that themselves have lit- 
tle or no cementitious properties but when in finely divided form and the presence of moisture reacts with $\mathrm{CaOH}_{2}$ which is liberated during cement hydration at ordinary temperature to form more cementitious materials according to [7]. Pozzolan possesses the characteristics of reacting with free lime released during cement hydration to form stable insoluble calcium silicates to reduce sulfate, salt and chloride attacks [22]. Researches in cement and concrete technology have concentrated on the use of waste materials as a potential replacement as alternatives for cement in the concrete industry and the need to introduce new materials or recycled materials as cement replacement materials are gaining popularity and as a result of increasingly stringent environmental legislation [2]. Pozzolanic activity of a material can be assessed by the ability of the material to react with $\mathrm{Ca}(\mathrm{OH})_{2}(\mathrm{CH})$ by monitoring the consumption of $\mathrm{CH}$ or measuring the strength development. The pozzolan influence is dependent on the quality and quantity of active phases in the pozzolan [10].

Agricultural wastes generated from poultry farms, bakeries, confectioneries, and restaurants which can cause environmental pollution, if not properly disposed of. The increasing demand for cement can address the problem of dumping waste and drive sustainability via the proper utilization or recycling of these biogenic wastes such as eggshell ash. Eggshell ash is byproducts of agricultural wastes obtained from the calcination of eggshell powder at $500{ }^{\circ} \mathrm{C}$ to produce calcium oxide which has shown according to [20] that it is a good accelerator, thereby decreasing the setting time of cement [14]. Eggshell is composed of mostly $93.7 \%$ of calcium carbonates and other constituents like phosphates and magnesium which is similar to limestone, thus can be employed as a partial cement replacement material [2, 23]. Authors [20] investigated the effect of ESA from 0-2.5 wt. \% at an interval of $0.5 \mathrm{wt}$. \% on setting time of cement blend and observed that setting was accelerated as the ESA content was increased. They also observed that percentage reduction from $1.4-32 \mathrm{wt}$ \% and 2.8334 wt. \% for the initial and final setting times respectively as cement is replaced with the ESA content from 0-2.5 wt. \%. Authors [19] investigated the effect of ESA for cement replacement from $5-30$ wt. \% at an interval of 5 wt. \% on the concrete compressive strength and found that 10 wt. \% ESA cement blend produced an enhanced strength of $32.36 \%$ and $23.43 \%$ for 7 and 28 days compared with control. Authors [9] also investigated the replacement of cement with ESA from 1-5 wt. \% at an interval of $1 \mathrm{wt} \%$ and observed a similar trend of accelerated setting time as the ESA content was increased. It was also concluded that up to $3 \mathrm{wt} \%$ cement replacement with ESA produced a better strength compared with control. Authors [14] investigated the feasibility and viability of employing ESA and its effects on the water consistency and setting time of cement blend and It was seen that both setting time of the cement blended with ESA was shortened as the ESA content was increased from $0-2 \mathrm{wt}$. $\%$ at an interval of $0.5 \mathrm{wt}$. \%.

Locust bean pod husks are byproducts of agricultural wastes obtained from locust bean trees which are deciduous trees mostly grown and harvested in the Sub-Sahara Africa region as well as the Northern part of Nigeria [1]. The improper disposal of various agricultural waste such as rice husk, groundnut husk, corn cob, and locust beans is an environmental concern and thus, the necessity to convert these waste to useful materials since many calcined agricultural wastes are rich in amorphous silica such as rice husk ash, coal bottom ash, fly ash, groundnut shell ash, etc. [13, $15,18,24,26]$. These biomasses could be employed as partial cement replacement materials due to their potentials of enhancing the strength of cement blends despite clinker diminution as a result of the reaction of amorphous silica with available lime from ordinary cement hydration $[18,24]$. Authors [3] investigated the replacement of cement with up to 50 wt. \% LBWA at an interval of $5 \mathrm{wt}$. \% on the concrete strength and observed that an increase in the strength as the curing day progressed from 2 to 28 days for all cement blends with a higher strength value obtained at 28 days. The general trend was that the concrete compressive strength diminished steadily as the \% LBWA was gradually increased with cement replacement not up to $10 \mathrm{wt}$. \% providing the targeted concrete compressive strength of $20 \mathrm{~N} / \mathrm{mm}^{2}$. Authors [5] studied the use of LBWA as partial cement replacement in concrete structures and observed that as the cement replacement with LBWA led to a decrease in the concrete strength for grade 20, 25 and 30 with an increase in strengths as the curing days progressed. It also observed that beyond $10 \mathrm{wt}$. \% cement replacement with LBWA, the concrete compressive strength at 28 days for grades 20 , 25 and 30 were 22.33, 24.38 and $24.22 \mathrm{~N} / \mathrm{mm}^{2}$ respectively. Authors [4] investigated the effect of replacing LBPA on the setting times and ob- 
served that as the LBPA content increased up to $30 \%$, the initial and final setting time experienced retardation by $66.8 \%$ and $39.7 \%$ respectively while LBPA cement blends beyond 15 wt. \% resulted in a decrease in its concrete compressive strength in a decrease in its concrete compressive strength while the concrete mix workability diminished as the LBPA content was increased. The enhanced compressive strength of $15 \mathrm{wt}$ \% LBPA cement blend agreed with results from SEM - EDS and XRD which indicated Calcium Silicate Hydrate (C-S-H) gel compared to other samples. They also suggested that the nature of the LBPA in terms of the crystalline or amorphous influenced the setting time which was dependent on the process of obtaining the ash. Authors [17] observed that 7 days' strength of control was better than LBPA cement mortar since the hydration rate of OPC was more rapid compared with LBPA cement blends while the cement replacement with up to $12 \mathrm{wt}$. \% LBPA produces similar compressive strength in comparison with control. Authors [21] investigated the effect of replacing cement with LBPA between $0-25 \mathrm{wt}$. $\%$ at a $5 \mathrm{wt}$. \% interval and observed a decrease in the compressive strength by $46 \%$ as the LBPA was increased up to 25 wt. \% while 5 wt. \% LBPA cement blend produced similar strength to control. Authors [32] indicated that as the concentration of $\mathrm{KCl}$ was increased from $0-14 \mathrm{~g} / \mathrm{l}$, the concrete compressive strength of the OPC concrete increased for all 28 and 90days results. They suggested that the probable chemical reaction for the hydration of cement with $\mathrm{K}$ concentration is the reason for the retardation of the setting time attributed to the formation of muscovite. $\mathrm{K}_{2} \mathrm{Al}_{2} \mathrm{Si}_{6} \mathrm{Al}_{4} \mathrm{O}_{20}(\mathrm{OH})_{4}$ and the large size of potassium ions involved in the crystallization of muscovite leading to an increase in the void. Thus, the presence of $\mathrm{K}^{+}$ions results in retardation of the initial and final setting time.

\section{MATERIALS}

Superset cement CEM II A-L conforms to the NIS 444 standards obtained from Ashaka cement ltd, Gombe state. Eggshells were collected from chick hatcheries, bakeries, fast food joints and restaurants. The eggshell ash (ESA) was prepared by burning fowls' eggshells at a temperature of $500{ }^{\circ} \mathrm{C}$ for 1 hour to obtain complete ash while Locust bean pods (LBP) were collected from Badabdi community, Gombe state, Nigeria. The fine aggregate used was CEN-NORMSAND (DIN EN 196-1) which conforms to ISO 679 with a net weight of $1350 \pm 5 \mathrm{~g}$ as standard sand. The distilled water was employed for mortar preparation and a well quantifiable amount for paste preparation. Water is needed for the hydration reaction of cement and also to make it workable during mixing. Table 1 indicates the chemical composition of OPC, LBPA, and ESA while Table 2 presents the chemical composition of the various locust bean pod ash calcined at 800, 850 and $900^{\circ} \mathrm{C}$ at 1 and 2 hours respectively.

Table 1 - Chemical composition of Portland Cement, Locust bean pod ash and Eggshell ash

\begin{tabular}{|l|r|r|r|}
\hline \multicolumn{1}{|c|}{ Oxides } & \multicolumn{1}{c|}{$\begin{array}{c}\text { OPC, } \\
\text { wt. } \%\end{array}$} & $\begin{array}{c}\text { LBPA, } \\
\text { wt. } \%\end{array}$ & $\begin{array}{c}\text { ESA, } \\
\text { wt. } \%\end{array}$ \\
\hline $\mathrm{SiO}_{2}$ & 23.87 & 9.48 & 0.19 \\
\hline $\mathrm{Al}_{2} \mathrm{O}_{3}$ & 7.87 & 2.00 & 0.54 \\
\hline $\mathrm{Fe}_{2} \mathrm{O}_{3}$ & 3.94 & 18.94 & 0.34 \\
\hline $\mathrm{CaO}$ & 57.34 & 19.42 & 49.58 \\
\hline $\mathrm{MgO}$ & 1.76 & 5.95 & 0.82 \\
\hline $\mathrm{SO}_{3}$ & 1.05 & 0.70 & 0.51 \\
\hline $\mathrm{K}_{2} \mathrm{O}$ & 0.00 & 27.54 & 0.40 \\
\hline $\mathrm{Na}_{2} \mathrm{O}$ & 0.36 & 0.44 & - \\
\hline $\mathrm{P}_{2} \mathrm{O}_{5}$ & - & 7.71 & - \\
\hline $\mathrm{Mn}_{2} \mathrm{O}_{3}$ & - & 0.29 & - \\
\hline $\mathrm{TiO}_{2}$ & - & 0.15 & - \\
\hline $\mathrm{Cl}$ & - & 0.02 & - \\
\hline $\mathrm{Cr}_{2} \mathrm{O}_{3}$ & - & 0.04 & - \\
\hline $\mathrm{SrO}$ & - & 0.14 & - \\
\hline $\mathrm{LOI}$ & 3.81 & 7.19 & 47.62 \\
\hline $\mathrm{CaCO}$ & & & 88.49 \\
\hline Sum of Conc. & 100.00 & 100.00 & 100.00 \\
\hline
\end{tabular}

Table 2 - Chemical composition of different calcination temperature and time of LBPA

\begin{tabular}{|l|r|r|r|r|r|r|}
\hline Compounds & \multicolumn{2}{|c|}{$800^{\circ} \mathrm{C}$} & \multicolumn{2}{|c|}{$850^{\circ} \mathrm{C}$} & \multicolumn{2}{|c|}{$900{ }^{\circ} \mathrm{C}$} \\
\cline { 2 - 7 } & 1 hr. & 2 hrs. & 1 hr. & 2 hrs. & 1 hr. & 2 hrs. \\
\hline $\mathrm{SiO}_{2}$ & 6.66 & 6.48 & 9.48 & 9.43 & 9.44 & 9.69 \\
\hline $\mathrm{Al}_{2} \mathrm{O}_{3}$ & 3.28 & 3.34 & 2.00 & 2.98 & 1.90 & 1.73 \\
\hline $\mathrm{Fe}_{2} \mathrm{O}_{3}$ & 19.71 & 19.48 & 18.94 & 17.79 & 17.74 & 17.09 \\
\hline $\mathrm{CaO}$ & 18.37 & 18.33 & 19.42 & 18.58 & 18.40 & 18.19 \\
\hline $\mathrm{MgO}$ & 6.50 & 6.50 & 5.95 & 5.77 & 7.28 & 7.29 \\
\hline $\mathrm{SO}_{3}$ & 1.89 & 1.86 & 0.70 & 1.47 & 0.67 & 0.66 \\
\hline $\mathrm{K}_{2} \mathrm{O}$ & 26.42 & 26.39 & 27.54 & 27.75 & 26.44 & 27.39 \\
\hline $\mathrm{Na}_{2} \mathrm{O}$ & 1.47 & 1.47 & 0.44 & 0.50 & 0.43 & 0.33 \\
\hline $\mathrm{P}_{2} \mathrm{O}_{5}$ & 7.95 & 7.83 & 7.71 & 7.59 & 8.16 & 7.58 \\
\hline $\mathrm{Mn}_{2} \mathrm{O}_{3}$ & 2.82 & 2.83 & 0.29 & 0.28 & 0.31 & 0.29 \\
\hline $\mathrm{TiO}_{2}$ & 0.06 & 0.07 & 0.15 & 0.15 & 0.21 & 0.15 \\
\hline $\mathrm{Cl}$ & 0.02 & 0.03 & 0.02 & 0.03 & 0.04 & 0.03 \\
\hline $\mathrm{Cr}_{2} \mathrm{O}_{3}$ & 0.06 & 0.08 & 0.04 & 0.04 & 0.05 & 0.04 \\
\hline SrO & 0.19 & 0.15 & 0.14 & 0.15 & 0.15 & 0.15 \\
\hline $\mathrm{LOI}$ & 4.61 & 5.16 & 7.19 & 7.50 & 8.79 & 9.40 \\
\hline Sum Total & 100 & 100 & 100 & 100 & 100 & 100 \\
\hline
\end{tabular}




\section{PROCEDURE}

The locust bean pods were dried under the sun for three days, crushed to about $0.5 \mathrm{~mm}$ size using the jaw crusher and then burnt locally using charcoal-burner though the pod was not allowed to make contact with the charcoal. Ten grams (10 g) of the initially burnt locust beans sample were weighed and then placed in an electric furnace. The samples were then calcined at different temperatures $\left(800^{\circ} \mathrm{C}, 850{ }^{\circ} \mathrm{C} \& 900{ }^{\circ} \mathrm{C}\right)$ for 1 hour \& 2 hours respectively to obtain the optimum temperature and time. Eggshells obtained from bakeries were sorted, sun-dried and crushed with a mortar and pestle. The ground eggshell powder was then calcined at a temperature of $500{ }^{\circ} \mathrm{C}$ at $1 \mathrm{hr}$. The resultant ashes from the calcination of the locust bean and eggshell powder were analyzed via a fused bead machine for the oxide analysis. One-gram (1 g) of the samples to be analyzed were weighed into a clean dry platinum crucible and 8 grams of X-ray flux (Granular) type Lithium tetraborate $66 \%$ and lithium metaborate $34 \%$ was weighed and mixed thoroughly with the sample. $1 \mathrm{ml}$ of $25 \% \mathrm{LiBr}$ solution using a $1 \mathrm{ml}$ pipette was added to avoid the sample from sticking to the platinum crucible. The prepared samples were then placed in VFD 4000 Fused Bead Machine and the machine was set ON for the process to begin. The beads were well labeled for proper identification and then ran through the XRF spectrometer on a reference curve program and the results were obtained. The ash content was purely obtained and the percentage loss was calculated for each of the heated samples and the optimum condition was determined at $850{ }^{\circ} \mathrm{C}$ for 1 hour.

Mortar compressive strengths of various cement blends were determined by compressive strength tests on mortar cubes compacted using a standard vibration machine. Standard sand was used for the preparation of cement mortar with the specimens set in $70.6 \mathrm{~mm}$ cubes (EN 196-1). The compressive strength tests of mortar samples were determined according to ASTM specification C39 after 2, 7 and 28 days of standard curing. The test specimens are stored in moist air climatic chamber at $20{ }^{\circ} \mathrm{C}$ for 24 hours, after which it was removed, marked and submerged into clear fresh water at $20 \pm 2{ }^{\circ} \mathrm{C}$ until curing days at 2, 7 and 28 days. The water for curing was monitored daily to maintain the temperature as specified. The flexural strength tests were achieved by performing a surface point test on the prism by EN 1052-2 by applying load hori- zontally on the prism by a hydraulic jack. The pictures of dried eggshell, standard sand, eggshell ash, locust bean pod ash are shown in Figures 14 respectively.

Experimental Design Mix. The experimental matrix for LBPA-ESA cement blends with cement replacement between $0-10 \mathrm{wt}$. \% is presented in Table 3. Resource [6] standard mix ratio of mortar cubes which can be employed for internal walls and surfaces of great importance was adopted for this study. A water/cement ratio of 0.4 was employed in molding mortar cubes comprising of ESA of $2.5 \mathrm{wt} \%$, $5 \mathrm{wt} \%$, $7.5 \mathrm{wt}$. \% and 10 wt. \% which was gradually replaced with LBPA for different mixes.

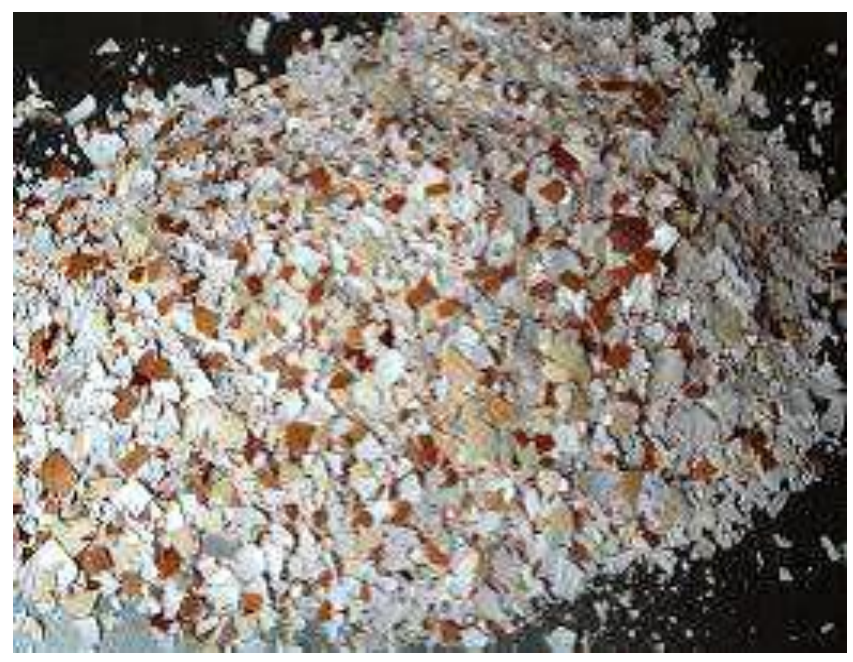

Figure 1 - Dried Eggshell

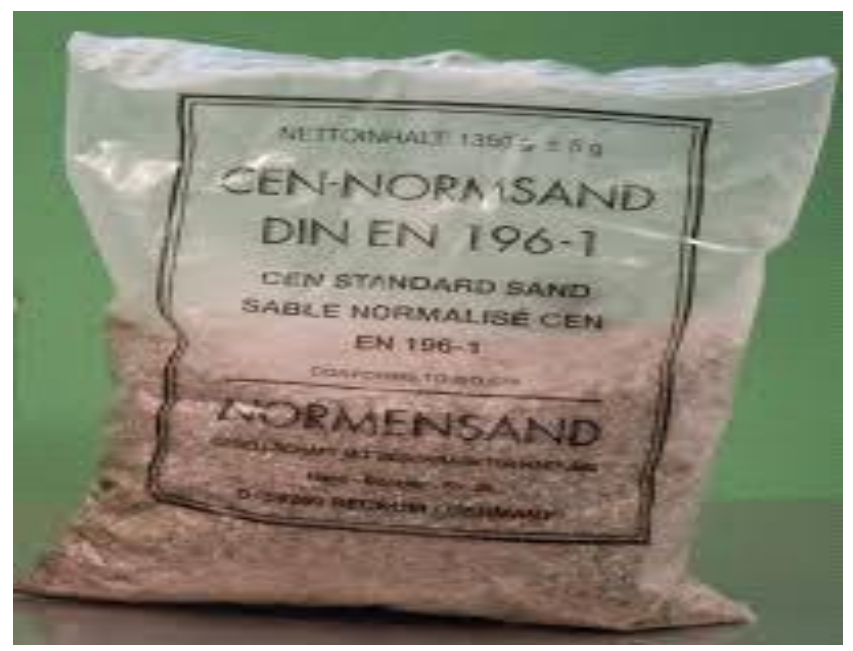

Figure 2 - Standard Sand EN 196-1 


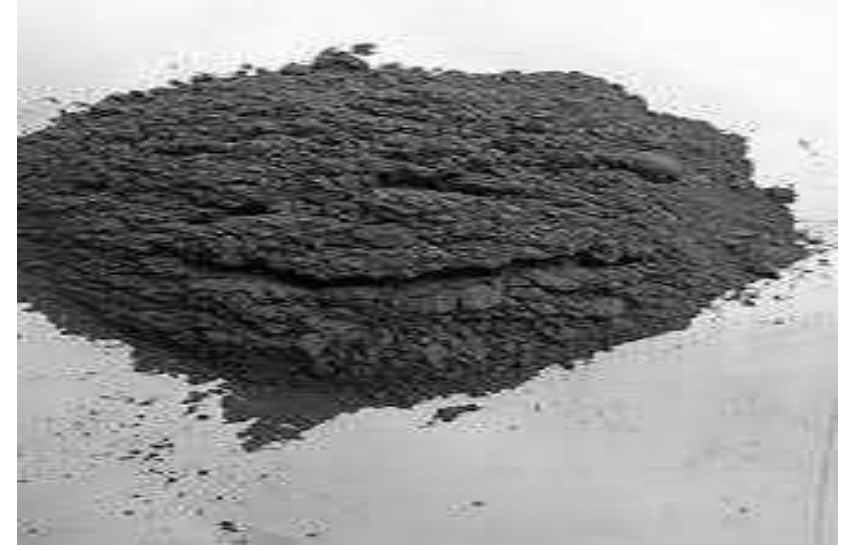

Figure 3 - Eggshell Ash

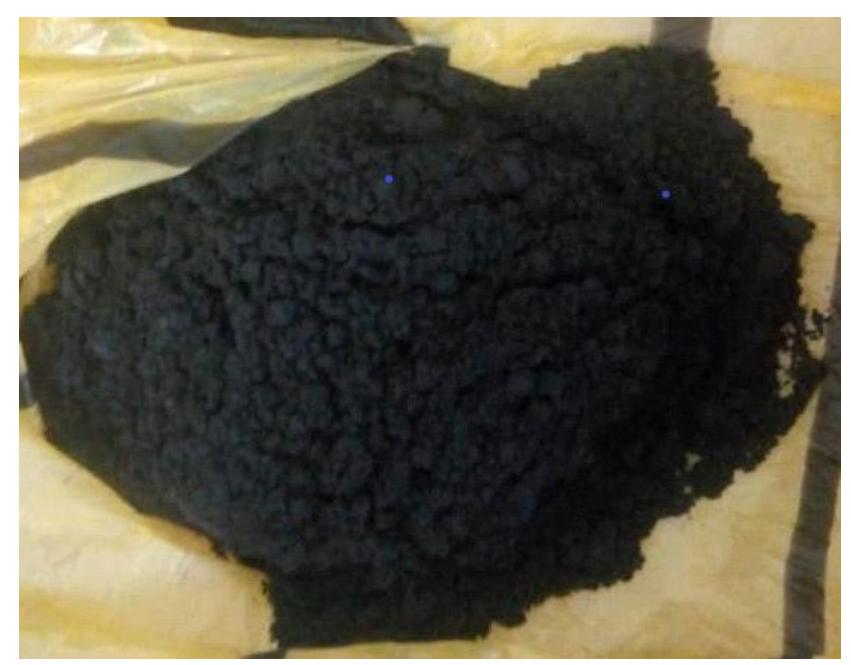

Figure 4 - Locust Beans Pod Ash

\section{RESULTS AND DISCUSSION}

The chemical composition obtained from the XRF analysis of OPC, LBPA, and ESA were presented in Table 1 . The percentage of reactive silicates content of CEM II A-L $42.5 \mathrm{~N}$ contains 23.87 wt. \% which is higher than 9.48 wt. \% for LBPA. The results of the chemical composition of LBPA indicates that it does not satisfy most requirements specified by [8] with $30.41 \mathrm{wt} . \%$ of $\mathrm{SiO}_{2}+\mathrm{Al}_{2} \mathrm{O}_{3}+\mathrm{Fe}_{2} \mathrm{O}_{3}$ which is less than 50 wt. $\%$ but satisfies the other requirements such as $\mathrm{SO}_{3}$ content of $0.7 \mathrm{wt}$. \% which is less than the maximum of 5 wt. $\%$ and LOI of 7.12 wt. \%, it contains $19.42 \mathrm{wt} \% \mathrm{CaO}$ which is within the range of 10 30 wt. \% $\mathrm{CaO}$ which fall into class $\mathrm{C}$ pozzolan. A similar trend was observed for [16] but obtained a lower $\mathrm{SiO}_{2}+\mathrm{Al}_{2} \mathrm{O}_{3}+\mathrm{Fe}_{2} \mathrm{O}_{3}$ content of $25 \mathrm{wt}$. \%. The XRF analysis of the calcined eggshell (ESA) reveals a high amount of $\mathrm{CaO}$ of 49.58 wt. \% $\left(\mathrm{CaCO}_{3} 88.49\right.$ wt. \%) along with minute quantities of $\mathrm{SiO}_{2}, \mathrm{Al}_{2} \mathrm{O}_{3}, \mathrm{Fe}_{2} \mathrm{O}_{3}, \mathrm{MgO}, \mathrm{SO}_{3}$, $\mathrm{K}_{2} \mathrm{O}$ and $\mathrm{Na}_{2} \mathrm{O}$ below 1 wt. \% while ESA LOI was 47.62 wt. \% which was high indicating the presence of non- decomposed limestone.

Author [33] revealed that eggshell was mainly composed of 93.70 wt. \% calcium carbonate, 4.20 wt. \% organic matter, 1.30 wt. \% magnesium carbonate, and 0.8 wt. \% of calcium phosphate. According to authors [30], the decomposition of $\mathrm{CaCO}_{3}$ to $\mathrm{CaO}$ (lime) was evident at about $820{ }^{\circ} \mathrm{C}$ in which $\mathrm{CaCO}_{3}$ is the main constituent and at $500{ }^{\circ} \mathrm{C}$, the weight loss of the calcined ESP could be due to dehydration of water and loss of organic matter to produce ESA.

Table 3 - Experimental Matrix for the various cement blends

\begin{tabular}{|l|l|c|c|c|c|c|c|c|}
\hline No & \multicolumn{1}{|c|}{ Blends } & LBPA / LBPA ESA & ESA, wt. $\%$ & LBPA, wt. $\%$ & OPC, $w t . \%$ & ESA, $g$ & LBPA, $g$ & OPC, $g$ \\
\hline 1 & 0ESA0LBPA & 0 & 0 & 0 & 100 & 0 & 0 & 500 \\
\hline 2 & 2.5ESA & 0 & 2.5 & 0 & 97.5 & 12.5 & 0 & 487.5 \\
\hline 3 & 2ESA0.5LBPA & 0.2 & 2 & 0.5 & 97.5 & 10 & 2.5 & 487.5 \\
\hline 4 & $1.5 E S A 1 L B P A$ & 0.4 & 1.5 & 1 & 97.5 & 7.5 & 5 & 487.5 \\
\hline 5 & $1.25 E S A 1.25 L B P A$ & 0.5 & 1.25 & 1.25 & 97.5 & 6.25 & 6.25 & 487.5 \\
\hline 6 & 1ESA1.5LBPA & 0.6 & 1 & 1.5 & 97.5 & 5 & 7.5 & 487.5 \\
\hline 7 & 0.5ESP2LBPA & 0.8 & 0.5 & 2 & 97.5 & 2.5 & 10 & 487.5 \\
\hline 8 & 2.5LBPA & 1 & 0 & 2.5 & 97.5 & 0 & 12.5 & 487.5 \\
\hline 9 & 5ESA & 0 & 5 & 0 & 95 & 25 & 0 & 475 \\
\hline 10 & 4ESA1LBPA & 0.2 & 4 & 1 & 95 & 20 & 5 & 475 \\
\hline 11 & 3ESA2LBPA & 0.4 & 3 & 2 & 95 & 15 & 10 & 475 \\
\hline 12 & 2.5ESA2.5LBPA & 0.5 & 2.5 & 2.5 & 95 & 12.5 & 12.5 & 475 \\
\hline 13 & 2ESA3LBPA & 0.6 & 2 & 3 & 95 & 10 & 15 & 475 \\
\hline 14 & 1ESP4LBPA & 0.8 & 1 & 4 & 95 & 5 & 20 & 475 \\
\hline 15 & 5LBPA & 1 & 0 & 5 & 95 & 0 & 25 & 475 \\
\hline 16 & 7.5ESP & 0 & 7.5 & 0 & 92.5 & 37.5 & 0 & 462.5 \\
\hline 17 & 6ESA1.5LBPA & 0.2 & 6 & 1.5 & 92.5 & 30 & 7.5 & 462.5 \\
\hline
\end{tabular}




\begin{tabular}{|l|l|c|c|c|c|c|c|c|}
\hline No & \multicolumn{1}{|c|}{ Blends } & LBPA / LBPA ESA & ESA, wt. \% & LBPA, wt. \% & OPC, $w t . \%$ & ESA, $g$ & LBPA, $g$ & OPC, $g$ \\
\hline 18 & 4.5ESA3LBPA & 0.4 & 4.5 & 3 & 92.5 & 22.5 & 15 & 462.5 \\
\hline 19 & 3.75ESA3.75LBPA & 0.5 & 3.75 & 3.75 & 92.5 & 18.75 & 18.75 & 462.5 \\
\hline 20 & 3ESA4.5LBPA & 0.6 & 3 & 4.5 & 92.5 & 15 & 22.5 & 462.5 \\
\hline 21 & 1.5ESA6LBPA & 0.8 & 1.5 & 6 & 92.5 & 7.5 & 30 & 462.5 \\
\hline 22 & 7.5LBPA & 1 & 0 & 7.5 & 92.5 & 0 & 37.5 & 462.5 \\
\hline 23 & 10ESA & 0 & 10 & 0 & 90 & 50 & 0 & 450 \\
\hline 24 & 8ESA2LBPA & 0.2 & 8 & 2 & 90 & 40 & 10 & 450 \\
\hline 25 & 6ESA4LBPA & 0.4 & 6 & 4 & 90 & 30 & 20 & 450 \\
\hline 26 & 5ESA5LBPA & 0.5 & 5 & 5 & 90 & 25 & 25 & 450 \\
\hline 27 & 4ESA6LBPA & 0.6 & 4 & 6 & 90 & 20 & 30 & 450 \\
\hline 28 & 2ESA8LBPA & 0.8 & 2 & 8 & 90 & 10 & 40 & 450 \\
\hline 29 & 10LBPA & 1 & 0 & 10 & 90 & 0 & 50 & 450 \\
\hline
\end{tabular}

Table 4 presents some determining physical properties of the cement CEM II A-L $42.5 \mathrm{~N}$ while the mortar compressive and flexural strengths of control specimen and 28 cement blends at various curing ages were determined and presented in Table 5.

Table 4 - Physical Properties of Control Sample (CEM II A-L 42.5N)

Property

Curing age, days \begin{tabular}{|c|c|c|}
2 & 7 & 28 \\
\hline
\end{tabular}

\begin{tabular}{|l|c|c|c|}
\hline Compressive Strength $\left(\mathrm{N} / \mathrm{mm}^{2}\right)$ & 23.84 & 38.99 & 48.18 \\
\hline
\end{tabular} \begin{tabular}{|l|c|c|c|}
\hline Flexural Strength $\left(\mathrm{N} / \mathrm{mm}^{2}\right)$ & 4.46 & 6.13 & 6.80 \\
\hline
\end{tabular} Setting Time (mins) Initial setting Water Consistency (\%) Expansion (mm)

Table 5 - Mortar Compressive and Flexural strengths of various cement blends and curing ages

\begin{tabular}{|l|l|c|c|c|}
\hline \multirow{2}{*}{ No } & \multirow{2}{*}{ Blends } & \multicolumn{3}{|c|}{$\begin{array}{c}\text { Compressive Strength } \\
\text { (Flexural Strength) } / \mathrm{mm}^{2}\end{array}$} \\
\cline { 3 - 5 } & & 2 -days & 7 -days & 28 -days \\
\hline 1 & \multirow{2}{*}{ OPC } & 23.84 & 38.99 & 48.18 \\
& & $(4.46)$ & $(6.13)$ & $(6.80)$ \\
\hline 2 & $2.5 E S A$ & 27.93 & 34.46 & 53.19 \\
& & $(4.61)$ & $(5.80)$ & $(7.33)$ \\
\hline 3 & 2 ESA0.5LBPA & 21.03 & 34.60 & 46.44 \\
& & $(3.91)$ & $(5.35)$ & $(6.42)$ \\
\hline 4 & $1.5 E S A 1$ LBPA & 26.74 & 32.77 & 50.15 \\
& & $4.43)$ & $(4.85)$ & $(6.82)$ \\
\hline 5 & $1.25 E S A 1.25$ & 21.91 & 29.05 & 47.21 \\
& LBPA & $(4.00)$ & $(4.25)$ & $(6.44)$ \\
\hline 6 & 1 ESA1.5 LBPA & 24.21 & 30.27 & 47.32 \\
& & $(4.38)$ & $(4.51)$ & $(6.71)$ \\
\hline 7 & $0.5 E S P 2 L B P A$ & 22.37 & 31.4 & 45.19 \\
& & $(4.30)$ & $(4.80)$ & $(6.37)$ \\
\hline 8 & 2.5 LBPA & 23.18 & 31.85 & 46.00 \\
& & $(4.31)$ & $(4.37)$ & $(6.43)$ \\
\hline 9 & 5ESA & 27.93 & 37.35 & 44.95 \\
& & $(5.10)$ & $(6.10)$ & $(6.30)$ \\
\hline
\end{tabular}

\begin{tabular}{|c|c|c|c|c|}
\hline \multirow[t]{2}{*}{ No } & \multirow[t]{2}{*}{ Blends } & \multicolumn{3}{|c|}{$\begin{array}{l}\text { Compressive Strength } \\
\text { (Flexural Strength) N/mm² }\end{array}$} \\
\hline & & 2-days & 7-days & 28-days \\
\hline 10 & 4ESA1LBPA & $\begin{array}{l}21.46 \\
(4.26)\end{array}$ & $\begin{array}{l}29.69 \\
(4.79) \\
\end{array}$ & $\begin{array}{l}43.00 \\
(6.20) \\
\end{array}$ \\
\hline 11 & 3ESA2LBPA & $\begin{array}{l}22.18 \\
(3.70)\end{array}$ & $\begin{array}{l}35.46 \\
(5.92)\end{array}$ & $\begin{array}{l}46.58 \\
(6.55) \\
\end{array}$ \\
\hline 12 & 2.5ESA2.5LBPA & $\begin{array}{l}17.16 \\
(3.33)\end{array}$ & $\begin{array}{l}30.80 \\
(4.54)\end{array}$ & $\begin{array}{l}39.83 \\
(6.37)\end{array}$ \\
\hline 13 & 2ESA3LBPA & $\begin{array}{l}21.01 \\
(3.37)\end{array}$ & $\begin{array}{l}34.46 \\
(5.80)\end{array}$ & $\begin{array}{l}46.57 \\
(6.50)\end{array}$ \\
\hline 14 & 1ESP4LBPA & $\begin{array}{l}23.08 \\
(4.14)\end{array}$ & $\begin{array}{l}30.60 \\
(4.19)\end{array}$ & $\begin{array}{l}47.20 \\
(6.37) \\
\end{array}$ \\
\hline 15 & 5LBPA & $\begin{array}{c}18.1 \\
(3.74)\end{array}$ & $\begin{array}{c}35.4 \\
(5.21)\end{array}$ & $\begin{array}{l}40.09 \\
(6.21)\end{array}$ \\
\hline 16 & 7.5ESP & $\begin{array}{l}17.77 \\
(3.40)\end{array}$ & $\begin{array}{l}32.77 \\
(4.85) \\
\end{array}$ & $\begin{array}{l}45.13 \\
(6.41) \\
\end{array}$ \\
\hline 17 & 6ESA1.5LBPA & $\begin{array}{l}21.93 \\
(3.75)\end{array}$ & $\begin{array}{l}34.25 \\
(5.11)\end{array}$ & $\begin{array}{l}46.62 \\
(6.51)\end{array}$ \\
\hline 18 & 4.5ESA3LBPA & $\begin{array}{l}19.11 \\
(3.62)\end{array}$ & $\begin{array}{l}33.19 \\
(5.42)\end{array}$ & $\begin{array}{l}48.10 \\
(6.71)\end{array}$ \\
\hline 19 & 3.75ESA3.75LBPA & $\begin{array}{l}18.65 \\
(3.57)\end{array}$ & $\begin{array}{l}29.67 \\
(4.79)\end{array}$ & $\begin{array}{l}35.76 \\
(6.19)\end{array}$ \\
\hline 20 & 3ESA4.5LBPA & $\begin{array}{l}16.89 \\
(3.01)\end{array}$ & $\begin{array}{l}32.79 \\
(4.11) \\
\end{array}$ & $\begin{array}{l}47.20 \\
(6.65)\end{array}$ \\
\hline 21 & 1.5ESA6LBPA & $\begin{array}{l}21.65 \\
(4.40)\end{array}$ & $\begin{array}{l}32.51 \\
(5.75)\end{array}$ & $\begin{array}{l}38.75 \\
(6.42)\end{array}$ \\
\hline 22 & 7.5LBPA & $\begin{array}{l}23.20 \\
(4.61)\end{array}$ & $\begin{array}{l}34.30 \\
(5.49)\end{array}$ & $\begin{array}{l}41.92 \\
(6.03)\end{array}$ \\
\hline 23 & 10ESA & $\begin{array}{l}23.71 \\
(4.42)\end{array}$ & $\begin{array}{l}36.52 \\
(5.16)\end{array}$ & $\begin{array}{l}43.18 \\
(6.99) \\
\end{array}$ \\
\hline 24 & 8ESA2LBPA & $\begin{array}{l}23.19 \\
(4.38) \\
\end{array}$ & $\begin{array}{l}33.66 \\
(5.71)\end{array}$ & $\begin{array}{l}48.00 \\
(6.75) \\
\end{array}$ \\
\hline 25 & 6ESA4LBPA & $\begin{array}{l}23.43 \\
(4.09)\end{array}$ & $\begin{array}{l}34.29 \\
(5.62)\end{array}$ & $\begin{array}{l}42.14 \\
(6.24)\end{array}$ \\
\hline 26 & 5ESA5LBPA & $\begin{array}{l}26.47 \\
(4.76)\end{array}$ & $\begin{array}{l}32.72 \\
(4.79)\end{array}$ & $\begin{array}{l}41.28 \\
(6.07)\end{array}$ \\
\hline 27 & 4ESA6LBPA & $\begin{array}{l}23.13 \\
(4.20)\end{array}$ & $\begin{array}{l}34.97 \\
(5.24)\end{array}$ & $\begin{array}{l}45.70 \\
(6.58)\end{array}$ \\
\hline 28 & 2ESA8LBPA & $\begin{array}{l}22.75 \\
(4.42)\end{array}$ & $\begin{array}{l}35.26 \\
(5.80)\end{array}$ & $\begin{array}{l}47.10 \\
(6.77)\end{array}$ \\
\hline 29 & 10LBPA & $\begin{array}{l}23.06 \\
(4.59)\end{array}$ & $\begin{array}{l}34.54 \\
(6.26)\end{array}$ & $\begin{array}{r}43.18 \\
(6.99) \\
\end{array}$ \\
\hline
\end{tabular}


Compressive strength of cement blended with ESA and LBPA. Figure 5 indicated that for $2.5 \mathrm{wt}$. \% cement replacement at 2 days, cement blends with higher ESA content produced better mortar compressive strengths than those with higher LBPA content especially at LBPA/LBPA-ESA ratios of $0,0.4$ and 0.6 respectively. Similar trends were observed for the ESA cement blend and limestone cement blend employed in [24] work.
This early strength of the cement blended with ESA (the calcium oxide present in ESA which is similar to limestone) could be attributed to the provision of more nucleation sites via the production of calcium hydroxide $(\mathrm{CH})$ at the early stage coupled with additional lime from ESA inclusion [11, 29] resulting in acceleration of the hydration rate, thereby resulting in accelerated early strength $[27,28]$.

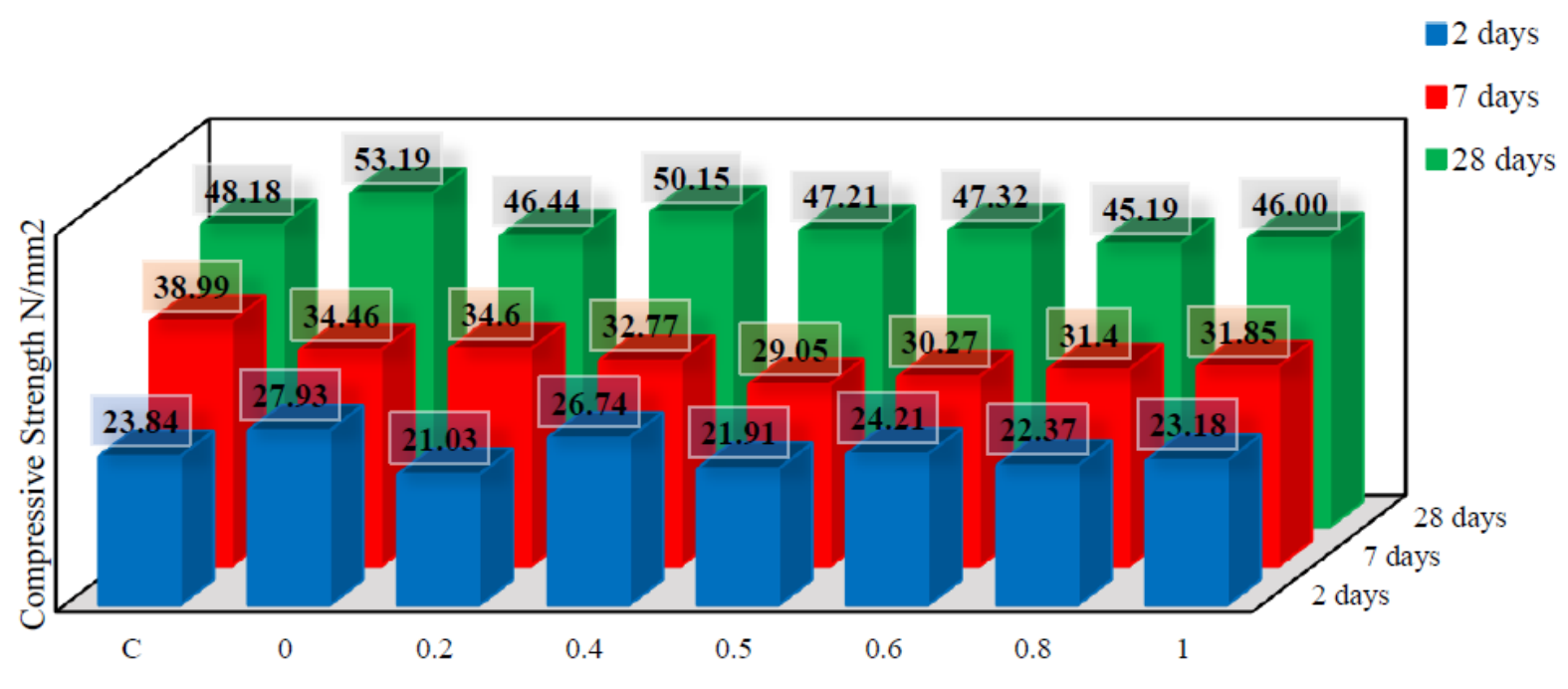

LBPA/LBPA-ESA ratio for $2.5 \%$ cement replacement

Figure 5 - Variation of SCM content and curing age on the mortar compressive strength at $2.5 \%$ cement replacement

Similarly, works by $[13,26,12]$ indicated that the inclusion of ESA (similar to limestone powder) could lead to the formation of monocarbonate, thus stabilizing ettringite at the expenses of monosulphate, thereby increasing the volume of the hydrates and in turn enhance its compressive strength of the cement blended with ESA. All cement blends at 2 days produced compressive strengths above $91 \%$ of the control strength as illustrated in Figure 5. The 7 days compressive strength for cement blends also produced better strengths for cement blends containing more ESA content than LBPA content with neither better than control.

It was also observed that the 28-day mortar compressive strength produced two cement blends with enhanced strength of $53.19 \mathrm{~N} / \mathrm{mm}^{2}$ and $50.15 \mathrm{~N} / \mathrm{mm}^{2}$ as against to control of $48.18 \mathrm{~N} / \mathrm{mm}^{2}$ at LBPA/LBPA-ESA ratio of 0 and 0.4 respectively. This enhanced strength could be attributed to the pozzolanic reaction from available lime and silica from LBPA despite diminution of clinker content resulting in the enhanced strength which was close to control. It could also be suggested that an increase in potassium content due to an increase in LBPA results in a gradual strength gain (retarder) due to the formation of muscovite $\mathrm{K}_{2} \mathrm{Al}_{2} \mathrm{Si}_{6} \mathrm{Al}_{4} \mathrm{O}_{20}(\mathrm{OH})_{4}$ [32] despite clinker diminution. The mortar compressive strength of all the blends experienced an increase as the curing day progressed as illustrated in Figures 6-8 respectively.

Figures 6-8 showed that all mortar compressive strengths at 2, 7 and 28 days for cement blends beyond 5 wt. \% replacement were either slightly or significantly lower than the control except for LBPA/LBPA-ESA ratio of 0.0 for 5 wt. \% cement replacement which produced a better 2 days compressive strength of $27.93 \mathrm{~N} / \mathrm{mm}^{2}$ against control compressive strength of $23.84 \mathrm{~N} / \mathrm{mm}^{2}$. 


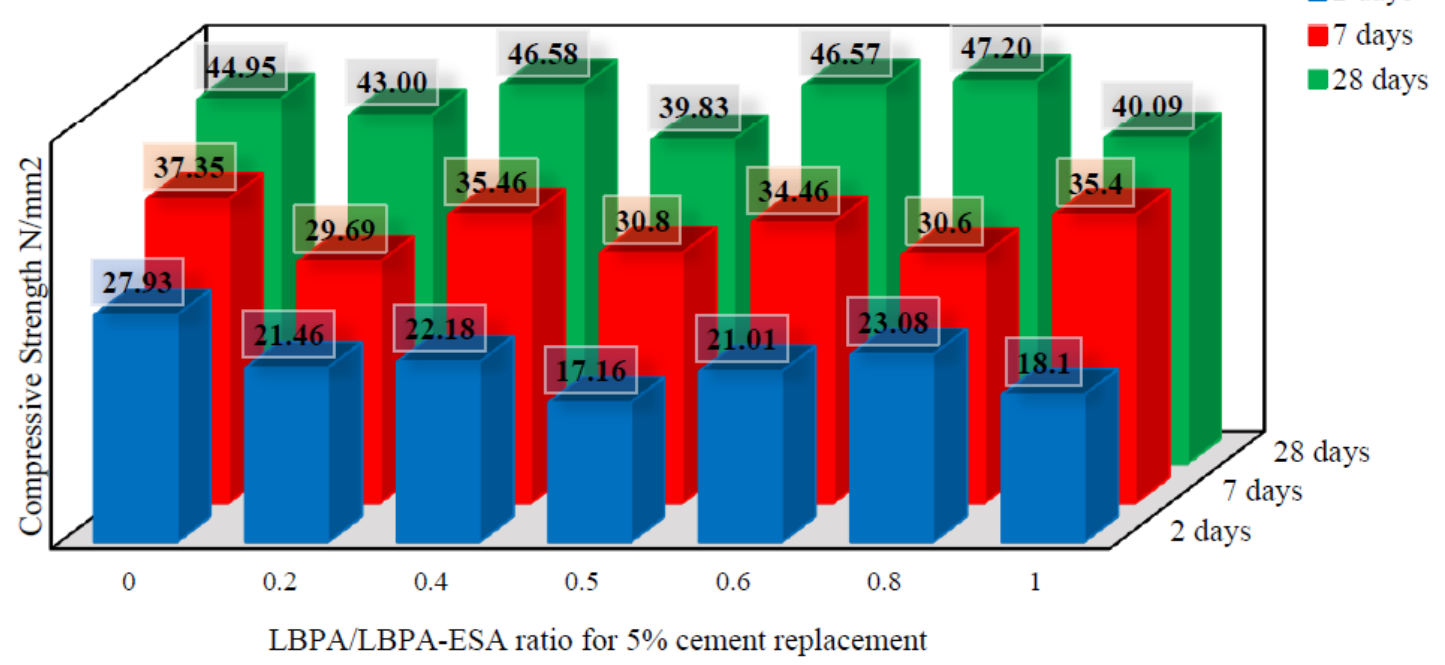

Figure 6 - Variation of SCM content and curing age on the mortar compressive strength at $5 \%$ cement replacement

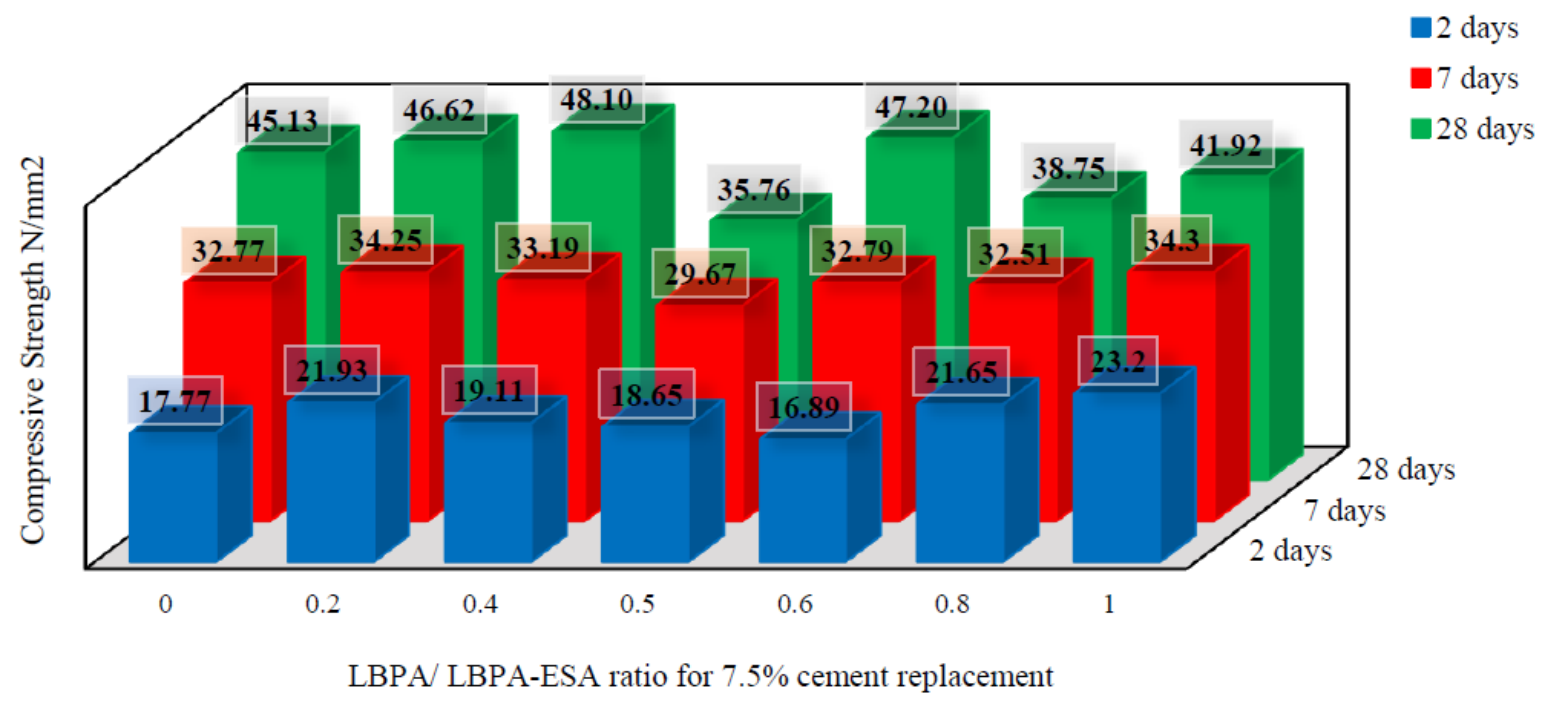

Figure 7 - Variation of SCM content and curing age on the mortar compressive strength at $7.5 \%$ cement replacement

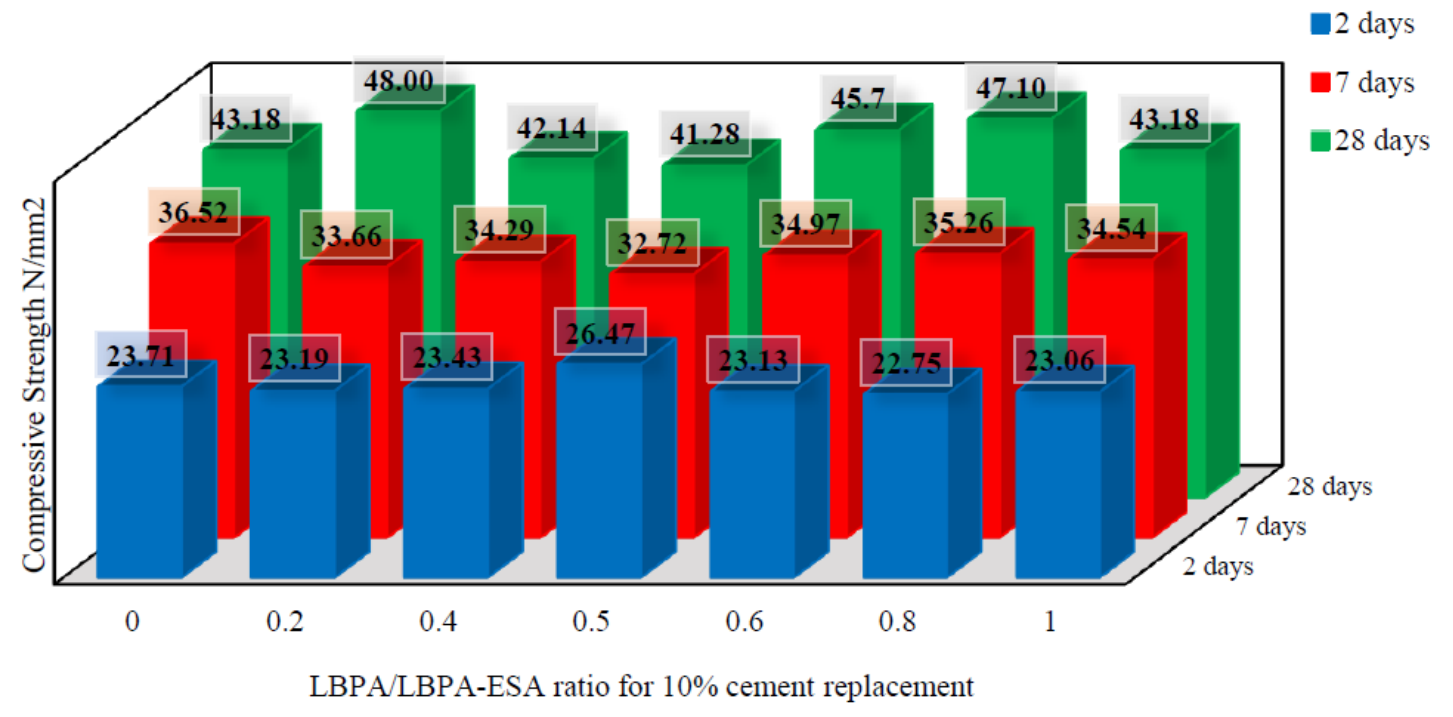

Figure 8 - Variation of SCM content and curing age on the mortar compressive strength at $10 \%$ cement replacement 
The reason for the enhanced strength despite cement replacement of $5 \mathrm{wt} . \%$ could be attributed to the pozzolanic reaction between the available lime from the hydration of calcium silicate and the silica present in the LBPA, resulting in the formation of more $\mathrm{CSH}$, leading to a denser and an enhanced strength which is in agreement with $[24,26]$ coupled with the formation of muscovite which also enhances the mortar compressive strength [32] as illustrated in equation (1).

$\mathrm{K}^{+}+3 \mathrm{Al}_{2} \mathrm{O}_{3}+7 \mathrm{SiO}_{2}+2 \mathrm{H}_{2} \mathrm{O}--\mathrm{K}_{2} \mathrm{Al}_{2} \mathrm{Si}_{6} \mathrm{Al}_{4} \mathrm{O}_{20}(\mathrm{OH})_{4}+\mathrm{SiO}^{2-}(1)$

Similar trends of improved strength despite the reduction in the clinker content were observed for $7.5 \mathrm{wt}$. \% and $10 \mathrm{wt} \%$ cement replacement with LBPA and ESA as illustrated in Figures 7 and 8 respectively. The inclusion of $\mathrm{CH}$ crystals from ESA on the hydration of calcium silicates tends to enhance the early rate of cement hydration by the provision of more nucleation sites, thereby resulting in accelerated early strength which agrees with [11, 29, 27, 25]. Figure 8 indicated that Cement blends produced enhanced strengths at early ages between 2 and 7 days for LBPA/ LBPA-ESA ratio of $0.4,0.6$ and 1 respectively in comparison with control with hydration rate ranging from $23.6 \%$ to $54.98 \%$ for cement blends compared to $63.55 \%$ for control. Similar mortar compressive strength for blends with
10 wt. \% cement replacement compared with the control despite clinker diminution.

Flexural strength of cement blended with ESA and LBPA. The variation of LBPA, ESA content and curing age on the mortar flexural strength of cement blends at various cement replacement of 2.5, 5, 7.5 and 10 wt. \% are illustrated in Figures 9-12 respectively. It could be also be observed from Figure 9 for $2.5 \mathrm{wt}$. \% cement replacement, that most of the blends at various LBPA/LBPAESA ratios produced slightly lower 28 days strengths compared with control, whereas cement blends with LBPA/LBPA-ESA ratio of 0 and 0.4 produced better strengths of $7.33 \mathrm{~N} / \mathrm{mm}^{2}$ and $6.82 \mathrm{~N} / \mathrm{mm}^{2}$ against the control of 6.8 $\mathrm{N} / \mathrm{mm}^{2}$ despite cement replacement.

Figure 10 indicated most cement blends produced lower 2 days flexural strength at $5 \mathrm{wt}$. \% cement replacement expect ESA cement blend with a flexural strength of $5.10 \mathrm{~N} / \mathrm{mm}^{2}$ against control strength of $4.46 \mathrm{~N} / \mathrm{mm}^{2}$. All blends produced lower flexural strengths for 28 days ranging from $6.2-6.55 \mathrm{~N} / \mathrm{mm}^{2}$ as against $6.8 \mathrm{~N} / \mathrm{mm}^{2}$ for control with a similar trend of lower 7 days flexural strength of cement blends compared to control at 5, 7.5, and $10 \mathrm{wt}$. \% cement replacement respectively. It also observed that most of the cement blends with $7.5 \mathrm{wt}$ \% cement replacement produced slightly close 28 days flexural strengths compared to control despite clinker diminution as illustrated in Figure 11.

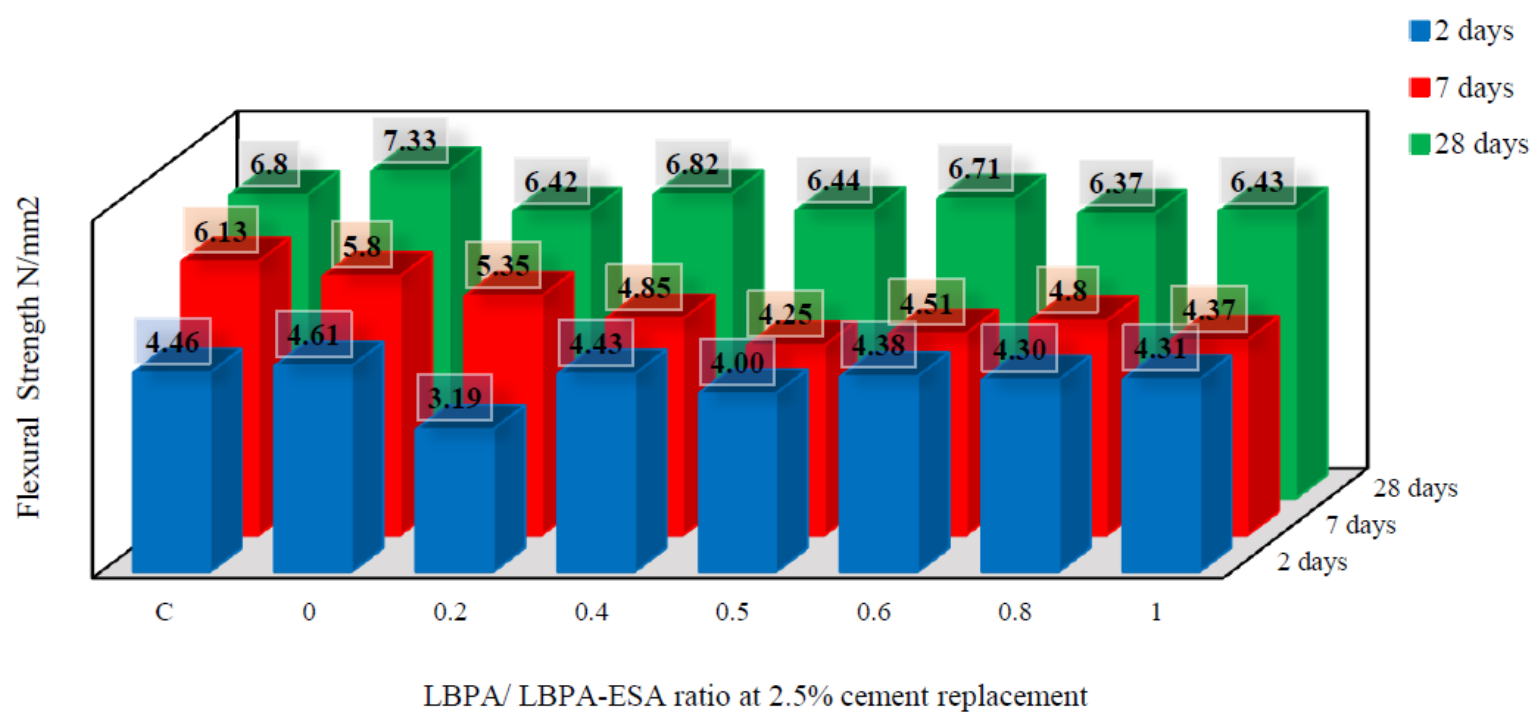

Figure 9 - Variation of SCM content and curing age on the mortar flexural strength at $2.5 \%$ cement replacement 


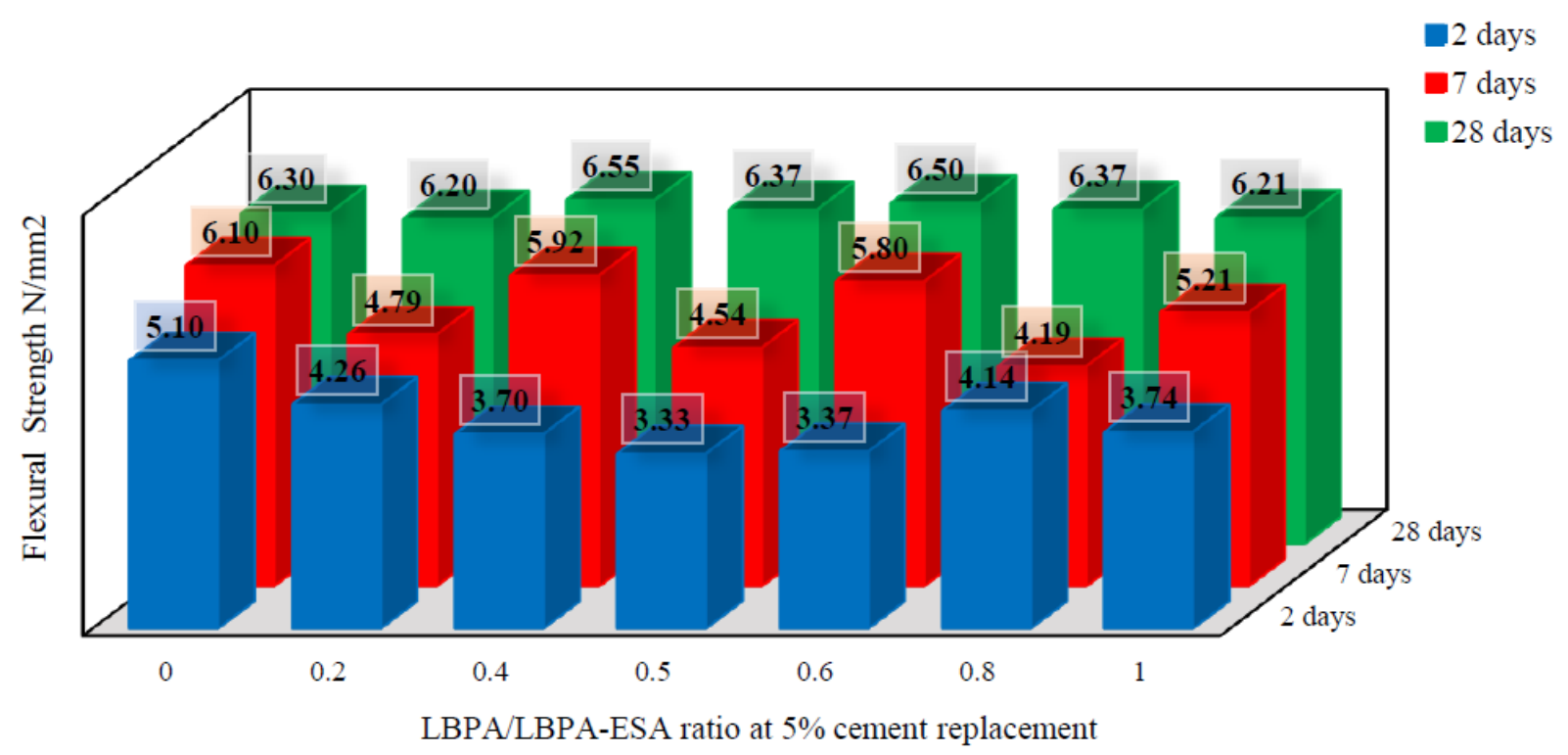

Figure 10 - Variation of SCM content and curing age on the mortar flexural strength at $5 \%$ cement replacement

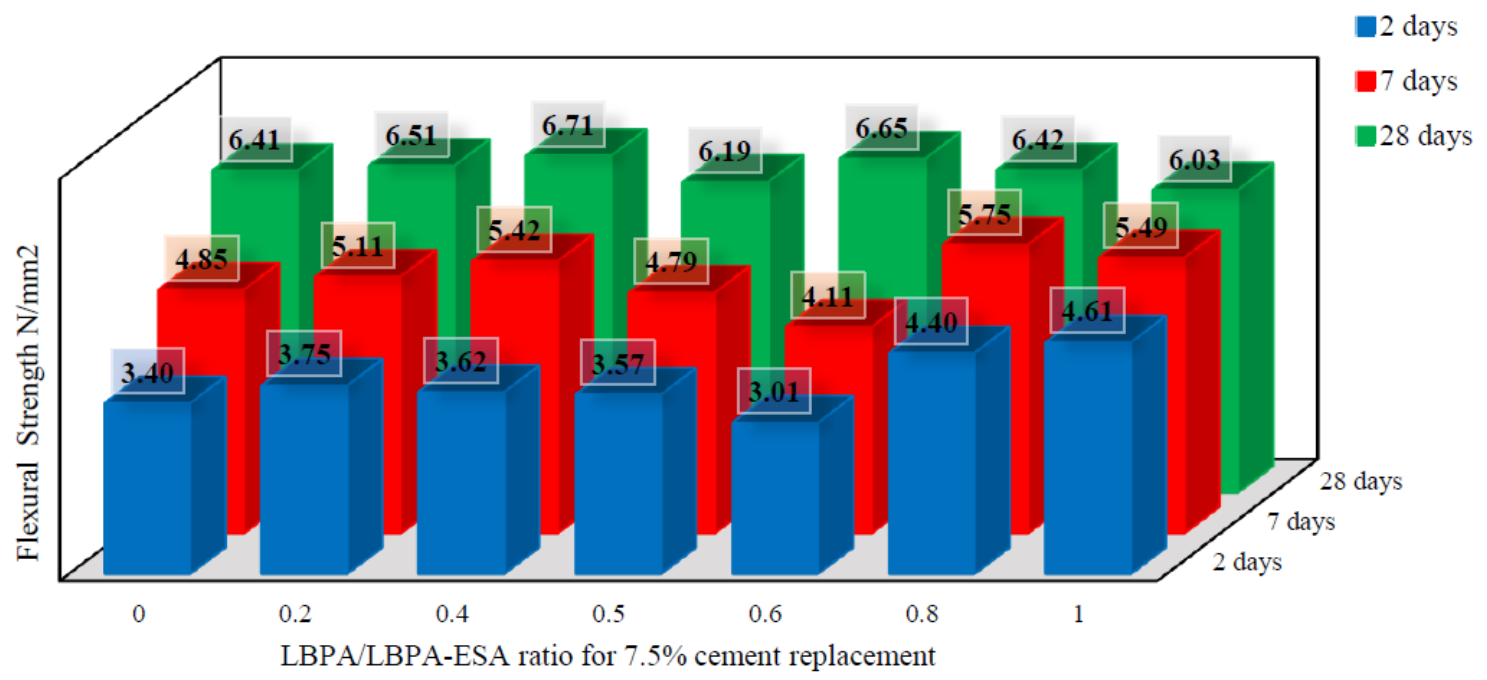

Figure 11 - Variation of SCM content and curing age on the mortar flexural strengths at $7.5 \%$ cement replacement

Figure 12 indicated that despite clinker diminution for 10 wt. \% ESA and 10 wt. \% LBPA cement blends produced better 28 days flexural strengths of $6.99 \mathrm{~N} / \mathrm{mm}^{2}$ than control while LBPA/LBPA-ESA ratios of 0.2 and 0.8 produced strength slightly close to the control of 6.75 and $6.77 \mathrm{~N} / \mathrm{mm}^{2}$ respectively which despite the clinker diminution. Similarly, it was also seen that the 2 days flexural strength for LBPA/LBPAESA ratios of 0.5 and 1 produced improved flexural strengths of $4.76,4.59 \mathrm{~N} / \mathrm{mm}^{2}$ as against control of $4.46 \mathrm{~N} / \mathrm{mm}^{2}$ respectively while at
7 days flexural strength for 10 wt. \% LBPA cement blend obtained an enhanced strength of $6.26 \mathrm{~N} / \mathrm{mm}^{2}$ against $6.13 \mathrm{~N} / \mathrm{mm}^{2}$. This improved strength could be attributed to the pozzolanic activity of the cement blends.

The compressive strength of blended cement was expressed as a percentage of the rate of control cement at the same curing time and illustrated in Figures 13 and 14 for LBPA cement blend and ESA cement blend respectively. 


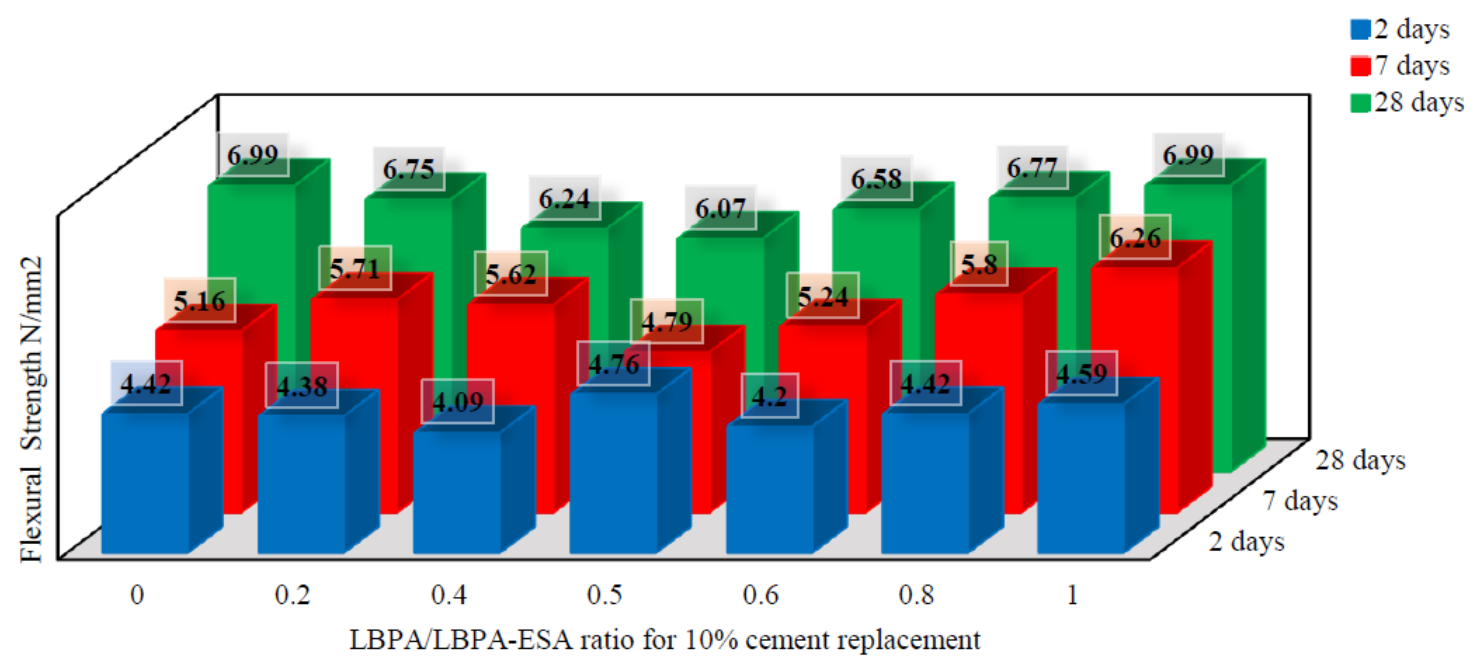

Figure 12 - Variation of SCM content and curing age on the flexural strengths at $10 \%$ cement replacement

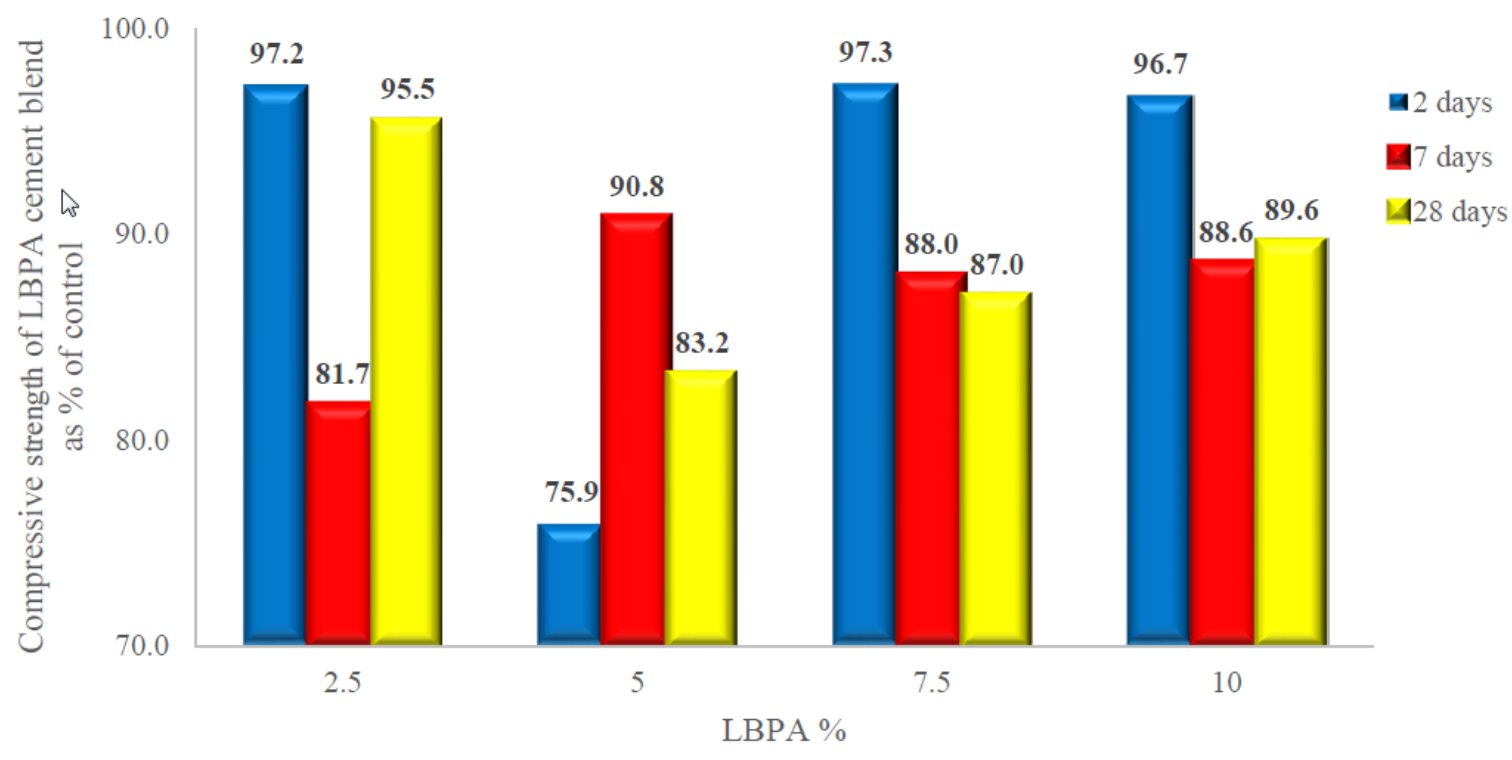

Figure 13 - Compressive Strengths of Blended LBPA as a percentage of control at various ages

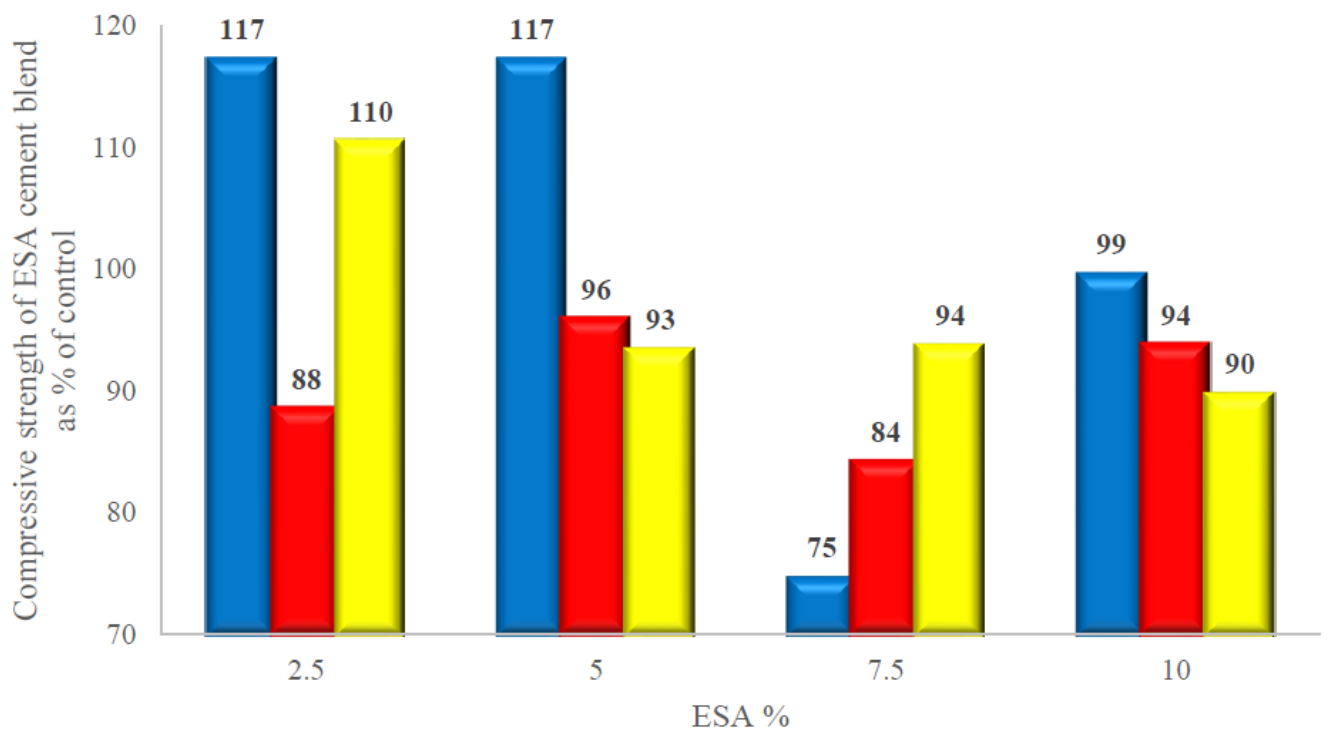

Figure 14 - Compressive Strengths of Blended ESA as a percentage of control at various ages 
Cement blended with LBPA for 2.5-10 wt. \% at an interval of $2.5 \mathrm{wt}$. \%, all produced mortar strengths lower than those of control at various curing days respectively. It was also seen that cement blended with $10 \mathrm{wt}$. \% LBPA produced up to $90 \%$ of the control strength despite clinker diminution is an indication of a pozzolanic reaction between silica present in LBPA and the available $\mathrm{CH}$ from cement hydration which is in agreement with [24]. LBPA cement blends of 7.5, 5 and $2.5 \mathrm{wt}$. \% cement replacement produced the best strength of $97.3,90.8$ and $95.5 \%$ of the control strength for 2, 7 and 28 days respectively. Whereas Cement blended with ESA for 2.510 wt. \% at an interval of 2.5 wt. \%, most of the mortar strength produced were lower than those of control except cement blended with 2.5 wt. \% and 5 wt. \% ESA at 2 days and $2.5 \mathrm{wt}$. \% ESA at 28 days with the best strength of 117, 110, and $117 \%$ respectively. This enhanced strength experienced especially at 2 days could be attributed to the provision of nucleation site, thus accelerating hydration rate which was in agreement with [13] and [26]. ESA cement blends of $2.5 \mathrm{wt}$. \% and $5 \mathrm{wt}$. \% produced strength of $117 \%$ in comparison with control for 2 days, $5 \mathrm{wt}$. \% cement replacement produced the best strength of $96 \%$ for 7 days whereas $2.5 \mathrm{wt}$. \% cement replacement produced the best strength of $110 \%$ for 28 days.

The flexural strengths for LBPA and ESA as a percentage of control are illustrated in Figures 15 and 16 respectively. It could be observed that as the LBPA content was increased from 2.5$5 \mathrm{wt}$. \%, the flexural strength increased compared with control strength beyond which any further increase led to a lower strength at 2 days. A similar trend was also observed at 7 days with $5 \mathrm{wt}$ \% LBPA producing similar strength with control beyond which produced lower flexural strength whereas, for 28 days flexural strength only 2.5 and 10 wt. \% LBPA produced enhanced strength despite cement replacement indicating pozzolanic activity. Similarly, the enhanced strength could be attributed to the presence of potassium, thus increase the flexural strength, especially at 28 days. $5 \mathrm{wt}$ \% LBPA cement blend produced the best 2 and 7 days flexural strength while $2.5 \mathrm{wt}$. \% LBPA cement blend produced the best 28 days as illustrated in Figure 15.

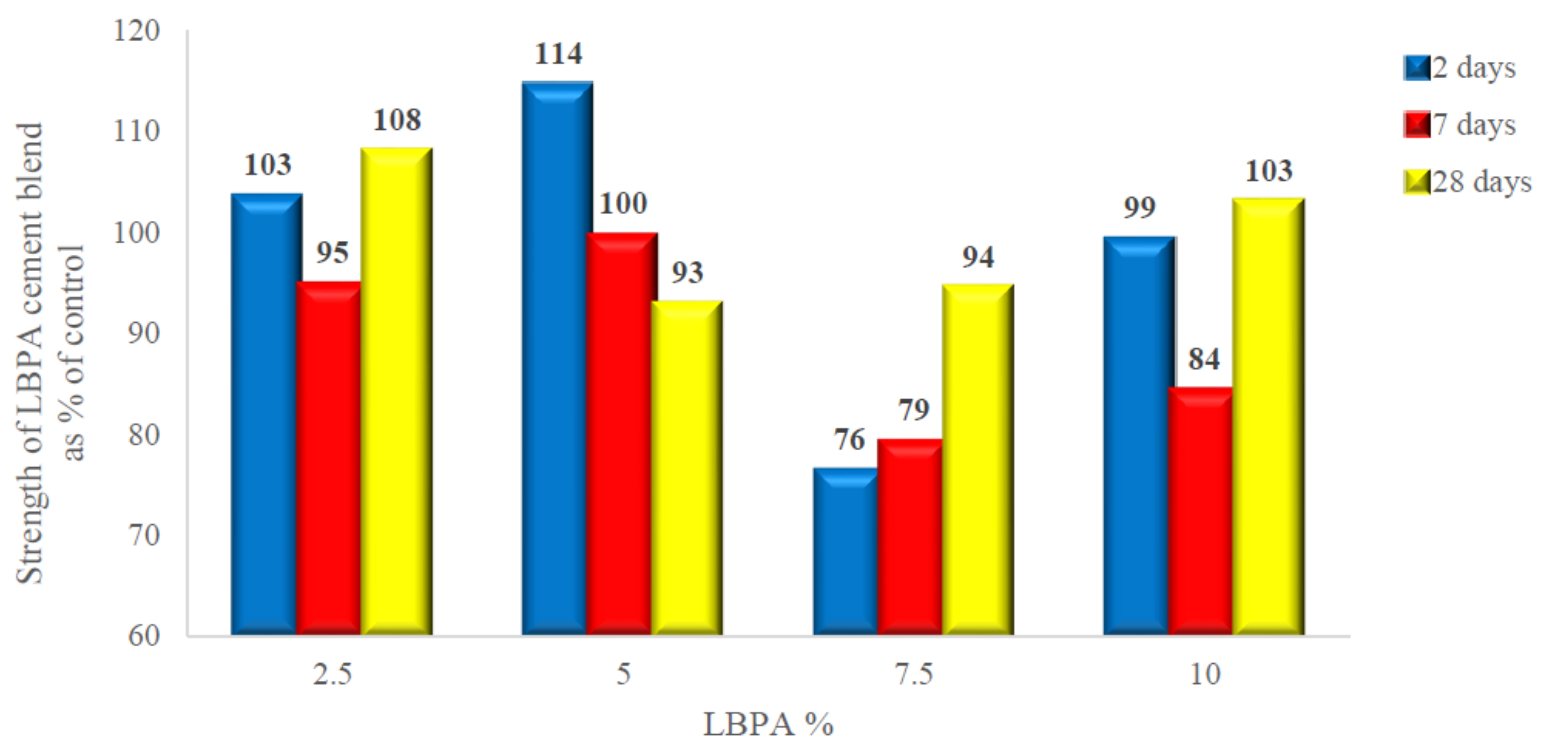

Figure 15 - Flexural Strengths of Blended LBPA as a Percentage of Control at various Ages

The 2 days flexural strength of the ESA cement blend produced enhanced strength at 7.5 wt. \% and $10 \mathrm{wt}$. \%. The 7 days strength was seen to increase as the ESA content was increased from 2.5-10 wt. \% with only 10 wt. \% ESA content producing a better flexural strength than the control. Only 10 wt.\% ESA cement blend for 28 days flexural strength produced a better strength than control. This could be attributed to the increased early hydration rate due to the provision of nucleation sites from the availability of $\mathrm{CH}$ present in the matrix [26]. Figure 16 indicates that 7.5 and $10 \mathrm{wt}$ \% ESA cement blends both produced the highest flexural strengths at 2 days as a percentage of control at approximately $103 \%$ respectively. It was also observed that $10 \mathrm{wt}$. \% of cement blended with ESA produced the highest flexural strength as a percentage of the control at 7 and 28 days. 


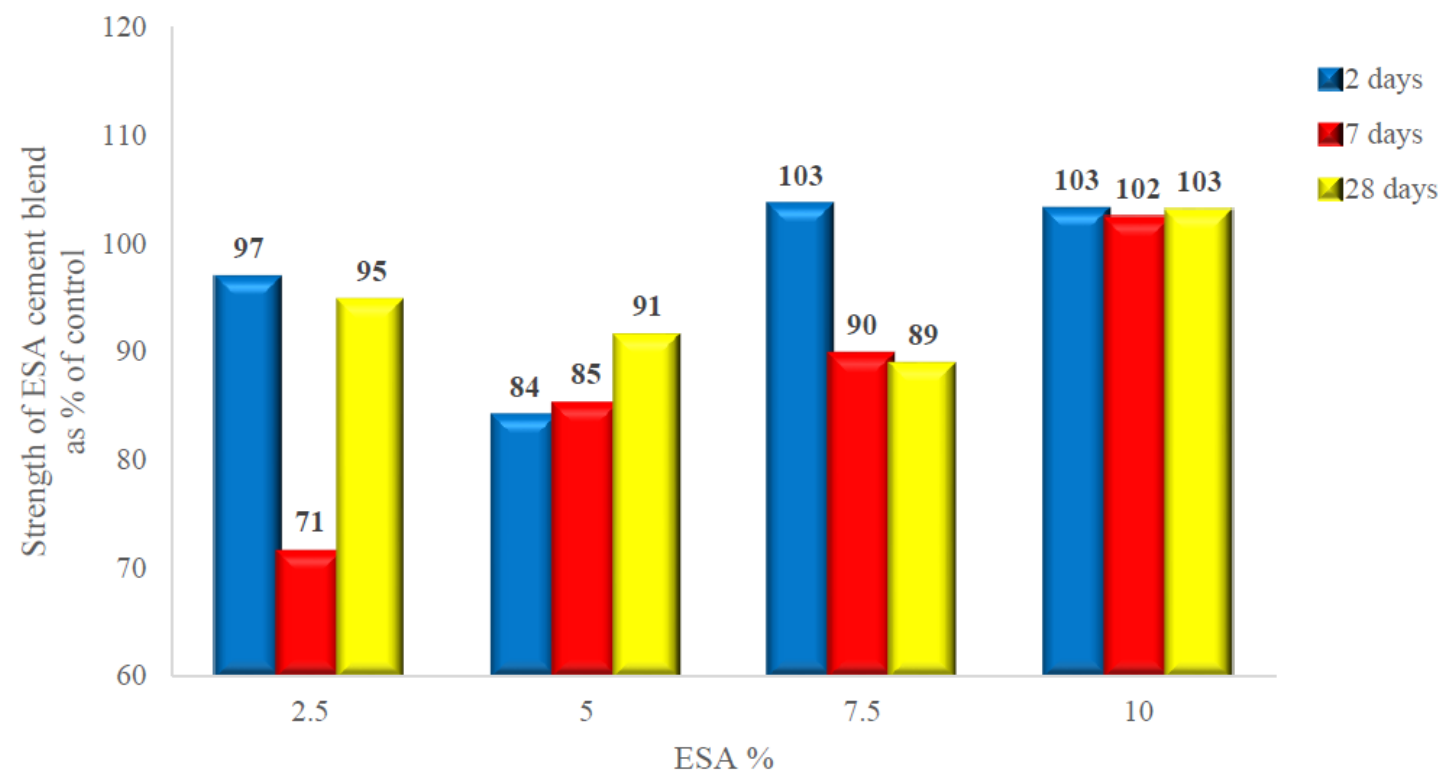

Figure 16 - Flexural Strengths of Blended ESA as a percentage of control at various ages

\section{CONCLUSION}

In this study, the potential of blending cement with LBPA and ESA were investigated on the mortar compressive and flexural strength of cement blends and the following conclusions were drawn.

The chemical composition of LBPA did not satisfy one of the requirements specified by ASTM C618 [8] with $\mathrm{SiO}_{2}+\mathrm{Al}_{2} \mathrm{O}_{3}+\mathrm{Fe}_{2} \mathrm{O}_{3}$ of 30.42 wt. \% which is less than 50 wt.\% but satisfies the other requirements such as $\mathrm{SO}_{3}$ content of 0.7 wt.\% which is less than the maximum of $5 \mathrm{wt} . \%$ and LOI of 7.12 wt.\% and contains 19.42 wt.\% CaO which is within the range of $10-30 \mathrm{wt} . \% \mathrm{CaO}$ is class $C$ pozzolan. The increase in LBPA content (high potassium content) of cement blends resulted in gradual strength gain (retarder) due to the formation of muscovite $\mathrm{K}_{2} \mathrm{Al}_{2} \mathrm{Si}_{6} \mathrm{Al}_{4} \mathrm{O}_{20}(\mathrm{OH})_{4}$ despite the increased cement replacement with LBPA.

The mortar compressive strength of cement blends at the early age of 2 and 7 days produced better compressive strengths with higher ESA content compared to LBPA especially at LBPA/LBPA-ESA ratio of $0,0.4$ and 0.6 for $2.5 \%$ cement replacement. This better early strength gain could be attributed to the provision of more nucleation sites by the inclusion of ESA, thus accelerating the rate of cement hydration.

On the other hand, the enhanced strengths at 28 days of cement blended with various replacement from 2.5-10 wt. \% could be attributed to the pozzolanic reaction between the available lime and reactive silica from LBPA despite clinker diminution which was close to control. It could also be suggested that an increase in potassium content due to increase in LBPA content could lead to a gradual strength gain (retarder) due to the formation of muscovite $\mathrm{K}_{2} \mathrm{Al}_{2} \mathrm{Si}_{6} \mathrm{Al}_{4} \mathrm{O}_{20}(\mathrm{OH})_{4}$.

An increase in the mortar compressive strength of all cement blends was observed as the curing day progressed. It was also observed that most of the blends experienced an enhanced strength gain compared with control strength gain of $23.57 \%$ between 7 and 28 days while most of the cement blends produced enhanced strength gain ranging from $13.35-62.51 \%$ compared to control. This enhanced strength can be related to the pozzolanic activity which is evident despite clinker diminution coupled with the high potassium content from LBPA could be suggested to be the reason for enhanced strength gain, especially at 28 days according to [32].

A decrease in the mortar compressive strength of LBPA cement blends was experienced as the LBPA content was increased from 2.5 to $10 \mathrm{wt} . \%$ compared with control strength which was approximately $90 \%$ of the control strength despite cement replacement of LBPA up to 10 wt.\%, while an enhanced strength was observed for cement replacement with ESA for 2.5 and 5 wt. $\%$ at 2 days which agrees with the provision of nucleation sites resulting in enhanced early strength. The 28 days compressive strength 
was seen to diminish as the cement replacement with ESA was increased from 2.5-10 wt.\% at an interval of $2.5 \mathrm{wt} . \%$.

An increase in the flexural strength of LBPA cement blends was observed as the LBPA content was increased up to $5 \mathrm{wt}$. \%, beyond which produced lower 2 and 7 days' flexural strengths compared with control strength respectively. Whereas at 2.5 and $10 \mathrm{wt}$. \% cement replacement with LBPA produced enhanced 28 days' strength compared with control. This enhanced strength could be attributed to pozzolanic activity coupled with the presence of potassium ions despite diminution of clinker content resulting in enhanced strength especially at 28 days. A gradual increase in the 7 days flexural strength experienced a gradual increase as the cement was replaced with ESA content from 2.5-10 wt. \% with only $10 \mathrm{wt}$. \% ESA content producing a better flexural strength than the control. This could be attributed to the increased early hydration rate due to the provision of nucleation sites from the availability of $\mathrm{CH}$ present in the matrix. The 2 days flexural strength of the ESA cement blend produced enhanced strength at $7.5 \mathrm{wt}$. $\%$ and 10 wt. \% compared to control whereas, cement blended with 10 wt. \% ESA produced a better 28day flexural strength than control.

\section{ACKNOWLEDGMENT}

The authors wish to thank Ashaka Cement Plc and the Department of Chemical Engineering of Abubakar Tafawa Balewa University for providing infrastructure, facilities, and support to this research work.

\section{CONFLICT OF INTEREST}

The authors declared that they have no conflict of interest.

\section{REFERENCES}

1. Adama, A., \& Jimoh, Y. (2012). Effect of locust bean pod ash on strength properties of weak soils. $A U$ Journal of Technology, 16(1), 21-35.

2. Afizah Asman, N. S., Dullah, S., Lynn Ayog, J., Amaludin, A., Amaludin, H., Lim, C. H., \& Baharum, A. (2017). Mechanical Properties of Concrete Using Eggshell Ash and Rice Husk Ash As Partial Replacement Of Cement. MATEC Web of Conferences, 103, 01002. doi: $10.1051 /$ matecconf/201710301002

3. Afolayan J. (2017). Experimental Investigation of the Effect of Partial Replacement of Cement in Concrete with Locust Bean Waste Ash. International Journal of Engineering and Applied Sciences, 5(12), 42-47.

4. Akpenpuun, T. D., Akinyemi, B. A., Olawale, O., Aladegboye, O. J., \& Adesina, O. I. (2019). Physical, mechanical and microstructural characteristics of cement-locust bean pod ash mortar blend. Journal of Applied Sciences and Environmental Management, 23(3), 377. doi: 10.4314/jasem.v23i3.1

5. Ali, H., Babatunde, R. I., Ibrahim, A., \& B.O, A. (2019). Investigation of Locus Beans Waste Ash as Partial Replacement for Cement in Concrete Structures. International Journal of Advances in Scientific Research and Engineering, 5(4), 149-153. doi: 10.31695/ijasre.2019.33133

6. ASTM International. (2001). Standard Specification for Mortar for Unit Masonry (ASTM C270-01). doi: $10.1520 / \mathrm{c} 0270-01$

7. ASTM International. (2001). Standard Specification for Coal Fly Ash and Raw or Calcined Natural Pozzolan for Use as a Mineral Admixture in Concrete (ASTM C618-00). doi: 10.1520/c0618-00

8. ASTM International. (2019). Standard Specification for Coal Fly Ash and Raw or Calcined Natural Pozzolan for Use in Concrete (ASTM C618-19). doi: 10.1520/c0595_c0595m-19

9. Balamurugan, M., \& Santhosh, R. (2017). Influence of Egg Shell Ash on the Properties of Cement. Imperial Journal of Interdisciplinary Research, 3(4), 160-165. 
10. Black, L. (2016). Low clinker cement as a sustainable construction material. Sustainability of Construction Materials, 415-457. doi: 10.1016/b978-0-08-100370-1.00017-2

11. Bonavetti, V. (1998). Limestone filler cements: Interaction mechanism and its influence on mechanical properties (Doctoral dissertation), University of Center Buenos Aires State, Argentine.

12. Bonavetti, V. ., Rahhal, V. ., \& Irassar, E. . (2001). Studies on the carboaluminate formation in limestone filler-blended cements. Cement and Concrete Research, 31(6), 853-859. doi: 10.1016/s0008-8846(01)00491-4

13. De Weerdt, K., Kjellsen, K. O., Sellevold, E., \& Justnes, H. (2011). Synergy between fly ash and limestone powder in ternary cements. Cement and Concrete Composites, 33(1), 30-38. doi: 10.1016/j.cemconcomp.2010.09.006

14. Fazeera, U., Kamran, S., \& Yasmin, H. (2016). Viability of Eggshells ash affecting the setting time of cement. Retrieved from https://zenodo.org/record/1112185\#.XpIF1_37TDA

15. Georgescu, M., \& Saca, N. (2009). Properties of blended cements with limestone filler and fly ash content. Scientific Bulletin, Series B, 71(3), 11-22.

16. Ikumapayi, C. M. (2017). Crystal and microstructure analysis of Pozzolanic properties of bamboo leaf ash and locust beans pod ash blended cement concrete. Journal of Applied Sciences and Environmental Management, 20(4), 943. doi: 10.4314/jasem.v20i4.6

17. Ikumapayi, C., \& Akingbomire, S. (2018). Effects of Bamboo Leaf and Locust Beans Pod Ashes on Autogenous Shrinkage Strain and Compressive Strength of Mortar. Journal of engineering and engineering technology, 12(1), 49-53.

18. Kaya, A. (2010, September). A study on blended bottom ash cements (Master's thesis). Retrieved from http://etd.lib.metu.edu.tr/upload/12612504/index.pdf

19. Kumar, P., Vishwakarma, A., \& Soni, K. (2016). Laboratory Analysis of Cement Concrete Prepared with EggShells Ash. International Journal of Advanced Technology for Science \& Engineering Research, 1(6), 16-23.

20. Mtallib, M., \& Rabiu, A. (2009). Effects of EggShells Ash (ESA) on The Setting Time of Cement. Nigerian Journal of Technology, 28(2), 29-38.

21. Ndububa, E., \& Uloko, J. (2018, July). Locust Bean Pod Ash (LBPA) as a Pozzolanic Material in Concrete. Retrieved from https://www.researchgate.net/publication/326631966_LOCUST_BEAN_POD_ASH_LBPA_AS_A_ POZZOLANIC_MATERIAL_IN_CONCRETE

22. Ojewumi, M., Ayomide, A., Obanla, O., Awolu, O., \& Ojewumi, E. (2016). Pozzolanic properties of Waste Agricultural Biomass - African Locust Bean Pod Waste. World Journal of Environmental Biosciences, 6(3), 1-7.

23. Okonkwo, U. N., Odiong I. C., \& Akpabio, E. E. (2012). The effects of eggshell ash on strength properties of cement-stabilized lateritic. International Journal of Sustainable Construction Engineering and Technology, 13(1), 18-25.

24. Olubajo, O., \& Osha, O. (2013). Influence of bottom ash and limestone powder on the properties of ternary cement and mortar. International Journal of Engineering Research and Technology, 2(7), 1201-1212.

25. Olubajo, O., Osha, O., El- Nafaty, U., \& Adamu, H. (2014). Effect of water-cement ratio on the mechanical properties of blended cement containing bottom ash and limestone. Civil and Environmental Research, 6(12), 1-9.

26. Olubajo, O., Osha, O., El-Natafty, U., \& Adamu, H. (2017). A study on Coal bottom ash and limestone effects on the hydration and physico-mechanical properties of ternary cement blends (Doctoral thesis). Abubakar Tafawa Balewa University. 
27. Péra, J., Husson, S., \& Guilhot, B. (1999). Influence of finely ground limestone on cement hydration. Cement and Concrete Composites, 21(2), 99-105. doi: 10.1016/s0958-9465(98)00020-1

28. Ramachandran, V. S., \& Chun-Mei, Z. (1986). Thermal analysis of the $3 \mathrm{CaO} \cdot \mathrm{Al}_{2} \mathrm{O}_{3}-\mathrm{CaSO}_{4} \cdot 2 \mathrm{H}_{2} \mathrm{O}-$ $\mathrm{CaCO}_{3}-\mathrm{H}_{2} \mathrm{O}$ system. Thermochimica Acta, 106, 273-282. doi: 10.1016/0040-6031(86)85139-5

29. Soroka, I., \& Setter, N. (1977). The effect of fillers on strength of cement mortars. Cement and Concrete Research, 7(4), 449-456. doi: 10.1016/0008-8846(77)90073-4

30. Spelta, J. S. de O., \& Galdino, A. G. de S. (2018). Bioceramic composite: hen's eggshell characterization and main applications. Revista Ifes Ciência, 4(1), 9-20. doi: 10.36524/ric.v4i1.323

31. Tang, Ran An (2010, November). Compressive Strength of Normal strength Concrete (NSC) Using British Standard, Euro code and non-destructive test approaches (Bachelor's thesis). Retrieved from http://umpir.ump.edu.my/id/eprint/3297/1/TANG_JIAN_AN.PDF

32. Venkateswara, R., Kontham, G., Venkata, R., \& Chundupalli, S. (2011). Effect of Potassium Chloride (KCl) on Ordinary Portland Cement (OPC) Concrete. Research Journal of Chemical Sciences, 1(2), 103-107.

33. Winton, A. L., Winton, K. G. B., \& Lakhotia, R. L. (2003). Poultry eggs. Jodhpur: Agrobios. 